\title{
Harvest Systems and Analysis for Herbaceous Biomass
}

\author{
Jude Liu, Robert Grisso and John Cundiff \\ Additional information is available at the end of the chapter
}

http://dx.doi.org/10.5772/53875

\section{Introduction}

Biomass is a distributed energy resource. It must be collected from production fields and accumulated at storage locations. Previous studies of herbaceous biomass as a feedstock for a bioenergy industry have found that the costs of harvesting feedstocks are a key cost component in the total logistics chain beginning with a crop on the field and ending with a stream of size-reduced material entering the biorefinery. Harvest of herbaceous biomass is seasonal and the window of harvest is limited. Biomass needs to be stored at a central location. Normally, several or many of these central storage locations in a certain range of a biorefinery are needed to ensure 24 hours a day and seven days a week supply. These centralized storage locations are commonly called satellite storage locations (SSL). The size and number of SSLs depend on the size of the biorefinery plant, availability of biomass within a given radius, window of harvest, and costs.

It is convenient to envision the entire biomass logistics chain from fields to biorefineries with three sections. The first section is identified as the "farmgate operations", which include crop production, harvest, delivery to a storage location, and possible preprocessing at the storage location. This section will be administrated by farm clientele with the potential for custom harvest contracts. The second section is the "highway hauling operations," and it envisions commercial hauling to transport the biomass from the SSL to the biorefinery in a cost effective manner. The third section is the "receiving facility operations," and it includes management of the feedstock at the biorefinery, control of inventory, and control of the commercial hauler contract holders to insure a uniform delivery of biomass for year-round operation.

Agricultural biomass has low bulk density, and it is normally densified in-field with balers, or chopped with a self-propelled forage harvester. Currently, there are four prominent harvesting technologies available for biomass harvesting [1]. They are: (1) round baling, (2) 
rectangular baling, (3) chopping with a forage harvester, and separate in-field hauling, and (4) a machine that chops and loads itself for in-field hauling (combined operation). Large round and large rectangular balers are two well-known and widely accessible harvesting technologies [2], which offer a range of advantages and disadvantages to farmgate operations. Round bales have the ability to shed water. When these bales are stored in ambient storage, they will store satisfactorily without covering and storage cost is significantly reduced. The round baler, because it is a smaller machine with fewer trafficability issues, can be used for more productive workdays during an extended harvest season over the winter months [3]. Large rectangular bales have greater bulk density, ease of transport, and increased baler productivity $(\mathrm{Mg} / \mathrm{h})$. However, the increased capital cost for the large rectangular baler and the bales' inability to shed water limit its use on farms in Southeastern United States. Bale compression machines are available to compress a large rectangular bale and produce high-density packages [4]. The densified package has two or three times higher density than the field density of large rectangular bales [5].

The goal of an effective logistics system is to streamline storage, handling, and preserve the quality of the biomass through the entire logistics chain. This goal will minimize average feedstock cost across year-round operation. The farmer shares the goal to preserve the quality of the biomass, and also desires to produce the biomass at minimum cost. To assist in the accomplishment of the mutual objectives of both parties, this chapter will discuss major logistics and machine systems issues starting from the farmgate to the receiving facilities at a biorefinery. Constraints in this biomass supply chain will also be discussed. The impact of different harvest scenarios for herbaceous biomass harvest will be shown. Logistics systems have been designed for many agricultural and forest products industries. Thus, it is wise to use the lessons learned in these commercial examples. Each of these industries faces a given set of constraints (length of harvest season, density of feedstock production within a given radius, bulk density of raw material, various storage options, quality changes during storage, etc.), and the logistics system was designed accordingly. Typically, none of these systems can be adopted in its entirety for a bioenergy plant at a specific location, but the key principles in their design are directly applicable. Commercial examples will be used in this chapter to interpret these principles.

\section{Biomass harvesting and the field performance of harvest machine systems}

\subsection{Introduction to herbaceous biomass harvesting}

Harvesting of cellulosic biomass, specifically herbaceous biomass, is done with a machine, or more typically a set of machines, that travel over the field and collect the biomass. These machines are designed with the traction required for off-road operation, thus they typically are not well suited for highway operation. Therefore, the transition point between "in-field hauling" and "highway hauling" is critical in the logistics system. In-field hauling is defined as the operations required to haul biomass from the point a load is created in-field to a 
storage location chosen to provide needed access for highway trucks. This hauling includes hauling in-field plus some limited travel over a public road to the storage location.

Harvesting systems can be categorized as coupled systems and uncoupled systems. Ideal coupled systems have a continuous flow of material from the field to the plant. An example is the wood harvest in the Southeast of the United States. Wood is harvested year-round and delivered directly to the processing plant. Uncoupled systems have various storage features in the logistics system.

Sugarcane harvesting is an example of a coupled system for herbaceous crops. The sugar cane harvester cuts the cane into billets about 38-cm long and conveys this material into a trailer traveling beside the harvester (Figure 1). The harvester has no on-board storage. Thus, a trailer has to be in place for it to continue to harvest. The trailer, when full, travels to a transfer point where it empties into a truck for highway hauling (Figure 2). Each operation is coupled to the operation upstream and downstream. It requires four tractors, trailers, and operators to keep one harvester operating. The trucks have to cycle on a tight schedule to keep the trailers moving. One breakdown delays the whole operation.

A "silage system" can be used to harvest high moisture herbaceous crops for bioenergy. With this system, a forage harvester chops the biomass into pieces about one inch $(25.4 \mathrm{~mm})$ in length and blows it into a wagon beside the harvester. This wagon delivers directly to a silo (storage location), if the field is close to the silo, or it dumps into a truck for a longer haul to the silo. All operations are coupled. That is, a wagon must be in place to keep the harvester moving, and a truck must be in place at the edge of the field to keep the wagons cycling back to the chopper. It is a challenge to keep all these operations coordinated.

A coupled system can work very efficiently when an industry is integrated like the sugarcane industry in South Florida, USA. Because the sugar mill owns the production fields surrounding the mill and the roads through these fields, the mill controls all operations (harvesting, hauling, and processing). Sugarcane has to be processed within 24 hours after harvest so the need for a tightly-controlled process is obvious.

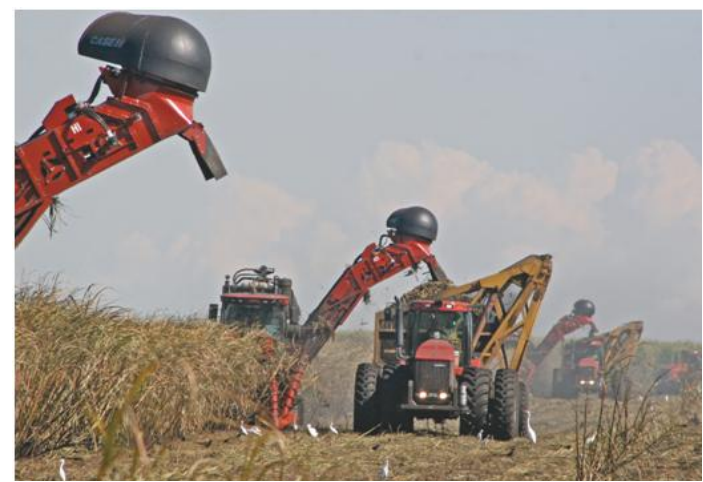

Figure 1. Sugar cane harvester delivering material into a dump trailer for delivery to edge of field (Photo by Sam Cooper, courtesy of Sugar Journal, P.O. Box 19084, New Orleans, LA 70179). 


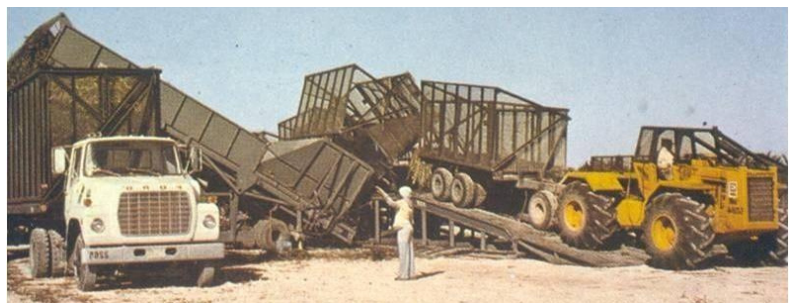

Figure 2. Transfer of sugar cane from in-field hauling trailers to highway-hauling trucks.

An example of an uncoupled system is cotton production using the cotton harvester that bales cotton into 7.5 -ft diameter by 8 -ft long round bales of seed cotton. This system was developed to solve a limitation of the module system. With the module system, in-field hauling trailers (boll buggies), have to cycle continuously between the harvester and the module builder at the edge of the field. The best organized system can typically keep the harvester processing cotton only about $70 \%$ of the total field time. Harvesting time is lost when the harvester waits for a trailer to be positioned beside the harvester so the bin on the harvester can be dumped.

Baling is an uncoupled harvest system and this offers a significant advantage. Harvesting does not have to wait for in-field hauling. Round bales, which protect themselves from rain penetration, can be hauled the next day or the next week. Rectangular bales have to be hauled before they are rained on.

\subsection{Field capacity and efficiency of biomass harvest machines}

The equipment used for baling and in-field hauling is a critical issue to the farm owners. More efficient harvest systems coupled with well-matched harvesting technologies specific to farm size and crop yield can minimize costs. The importance of understanding the linkage between various unit operations in the logistics chain was illustrated [6,7]. Similarly, researchers have quantified the handling and storage costs for large square bales at a bioenergy plant [8]. However, in both of these evaluations the details of field operations and field capacities of machines involved in the field harvesting and handling were not available [9]. Instead, costs of bales at the farm gate were used to analyze bioenergy production costs. To maximize the field efficiency of field machine systems, it is essential for farm managers to know the field capacity of each machine involved in harvesting. In addition, quantitatively understanding the capacity of biomass harvest machines is essential to assess daily production and supply rate for a biorefinery or a storage facility.

The field efficiency of rectangular balers can be determined by calculating the theoretical material capacity of the baler and actual field capacity [10]. Calculation of material capacity can be demonstrated using a large rectangular baler as an example. The end dimensions of the large bales were $1.20 \mathrm{~m} \times 0.90 \mathrm{~m}$; bale length was $2.44 \mathrm{~m}$. The depth and width of the chamber were $0.9 \mathrm{~m}$ and $1.2 \mathrm{~m}$, respectively. Plunger speed was 42 strokes per minute. Measured bale density was $146 \mathrm{~kg} / \mathrm{m}^{3}$, and the thickness of each compressed slice in bale 
was $0.07 \mathrm{~m}$. Thus, calculated theoretical bale capacity using equation 11.60 in [10] is 27.83 $\mathrm{Mg} / \mathrm{h}$. The plunger load could be set higher and produce higher density bales.

The theoretical capacity was obtained from a baler manufacturer under ideal conditions. Ideal conditions exist when a baling operation has [11]:

1. Long straight windrows

2. Windrows prepared with consistent and recommended density (mass/length)

3. Properly adjusted and functioning baler

4. Experienced operator

Actual field capacity of a baler will be impacted by the size and shape of the field, crop type, yield and moisture content of the crop at harvest, and windrow preparation. Typical field efficiencies and travel speeds can be found from ASAE Standards D497 [12]. Cundiff et al. [11] analyzed the field baler capacity and considered the effect of field size on baler field capacity. They found that the field capacities of round and large rectangular balers were 8.5 $\mathrm{Mg} / \mathrm{h}$ and $14.4 \mathrm{Mg} / \mathrm{h}$, respectively.

Another example of testing the baling capacity of a large rectangular would be the field tests conducted on wheat straw and switchgrass fields $[13,14]$. Results showed that actual field capacity of a large rectangular baler was between 11 and $13 \mathrm{Mg} / \mathrm{h}$. This indicates that the field capacity of a large rectangular baler could be $50 \%$ or less compared to its theoretical capacity.

\subsection{Power performance of harvest machine systems}

Machine system field efficiency is limited by tractor power performance, machine field capacity, and field conditions. Field conditions limit operational parameters and the percentage of the maximum available power. Since the high cost of harvest and in-field handling is still one of the main roadblocks of utilizing biomass feedstocks to produce biofuels, increasing machine system field efficiency through designing or selecting suitable machine systems is the challenge to machinery design and management professionals.

Power performance of a $2 \mathrm{WD}$ rear drive tractor was presented in a format of flow chart in ASAE standards $[12,15]$. Total power required for a tractor is the sum of PTO power $\left(P_{p t o}\right)$, drawbar power $\left(P_{d b}\right)$, hydraulic power $\left(P_{h y d}\right)$, and electric power $\left(P_{e l}\right)$ as expressed by equation (1). Depending on the type of implement, components in equation (1) may vary. Total power calculated with equation (2) is defined as equivalent PTO power, which can be used to estimate the tractor fuel consumption under specific field operations.

$$
P_{T}=\frac{P_{d b}}{E_{m} E_{t}}+P_{p t o}+P_{h y d}+P_{e l}
$$

Where $E_{m}$ and $E_{t}$ are mechanical efficiency of the transmission and tractive efficiency, respectively. Each of the power requirements in Equation (1) can be estimated using recommended equations in [12]. Example of using this standard to estimate power requirements for a large rectangular baler system is available [13]. 


\subsection{System analysis case study - Large rectangular bale handling systems}

\subsubsection{Baling and bale collection}

Baling, bale collecting, and bale storing of 650-ha wheat straw field at a commercial farm was studied as a typical large rectangular bale harvesting system. Factors that affect large rectangular bale production and handling logistics were quantified through observing complete field operations and then the system performance was analyzed and field capacities of all machines in this system was determined. System limitations were quantified, and means to reduce production costs were discussed [14].

Bales were stored in covered storage facilities. The equipment used included one large rectangular baler, two bale handlers, and three flatbed bale trucks (Figure 3). The straw was raked with a twin rotary rake. The rake was used to form uniform and evenly-spaced windrows from the straw that had been expelled by the combines. If the straw was rained on before baling, the rake fluffed the straw to enhance drying. The operator adjusted the swath of the rake in order to form windrows of proper size.

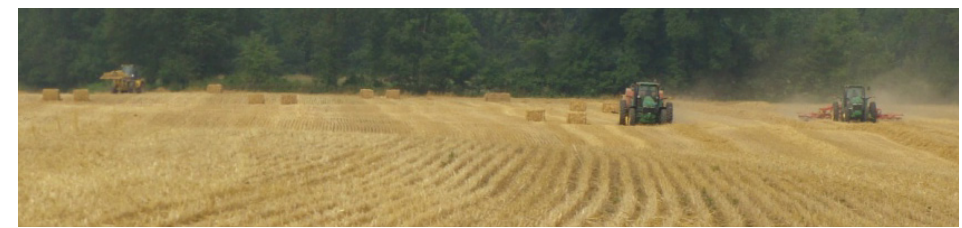

Figure 3. The large square baler, bale handler, and bale truck used in straw harvesting.

The field crew included a person operating the baler, two persons operating wheel loaders, and three truck drivers. The baler ran continuously throughout the day with the exception of operator breaks. Since no bales were left in the field overnight, the bales were collected at about the same pace as produced. A truck driver would bring the truck into the field and locate two bales. The wheel loader operator followed the truck through the field and loaded two bales at a time. When the truck was full, the driver would exit the field and transport the load to a storage facility. Bales were loaded in an interlocking manner, and the bales were not strapped down, a procedure that saved a lot of time.

Because there were three truck drivers and two trucks, a driver was not present while the truck was unloaded. The driver of the fully loaded truck would drive into the storage facility and position the truck to be unloaded. By the time this truck arrived with a full load of straw, the previous truck at the site would be empty. This process was repeated, with minor delays when a driver waited for a truck to be unloaded. Capacity of each operation was measured in terms of number of large rectangular bales (Table 1). Baling rate was the limiting factor in the system.

\subsubsection{Bale compression}

To reduce long distance hauling cost of forage/hay bales, compression of these bales into ultra-dense bales was adopted by some producers to prepare the hay for overseas transport. 
Commercial bale compression equipment has potential to be used for the densification of baled biomass.

\begin{tabular}{lc}
\hline Field operation & Number of bales per hour (St. dev.) \\
\hline Raking & 85 (equivalent) \\
\hline Baling & $43(9)$ \\
\hline Accumulating into stacks of bales in field & $93(28)$ \\
\hline Loading truck in field from accumulated bales & $204(29)$ \\
\hline $\begin{array}{l}\text { Loading truck in field from not first accumulated } \\
\text { bales }\end{array}$ & $143(46)$ \\
\hline Stacking bales in storage & $93(12)$ \\
\hline
\end{tabular}

Table 1. Field capacities of large rectangular baler and bale handlers (Straw M.C., 14\% w.b.) [14].

Ten large rectangular switchgrass bales were compressed using the compressor (Figure 4) [9]. The input bale had a dimension of $0.86 \times 1.22 \times 2.21 \mathrm{~m}$, and the resulting compressed bales were $0.53 \times 0.46 \times 0.38 \mathrm{~m}$. When stacked in groups of 20 per pallet, the package had a dimension of $1.02 \times 1.17 \times 1.70 \mathrm{~m}$. The initial bales had a volume of $23.27 \mathrm{~m}^{3}$. When accounting for a $7.0 \%$ loss of material and water, this volume was $21.67 \mathrm{~m}^{3}$. The bales had average moisture of $14 \%$ (w.b.) at the time of compression. The compressed package had a volume of $13.13 \mathrm{~m}^{3}$, a reduction of $60.6 \%$ in volume.

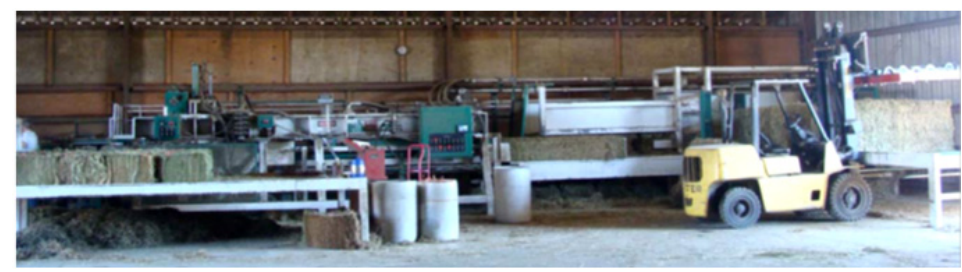

Figure 4. Commercial large rectangular bale slicer/compressor.

\subsection{System analysis case study - Round bale handling system}

The advantage of round bales is that the rounded top sheds water and bales can be stored in ambient storage without the expense of covered storage. A second important advantage of round bales is that round balers are conventional technology throughout the United States. They are widely used to harvest forage. Compared to a large rectangular baler, a round baler has lower capital cost.

A significant advantage is realized by the farmers if their round balers can be used for both their existing livestock enterprise and a bioenergy enterprise. Warm-season grasses are harvested during the winter for the bioenergy market. Thus, the biomass harvest does not conflict with the hay harvest. The advantage gained by the biorefinery is that no need for their feedstock producers to invest in new equipment. Requiring capitalization of new equipment will make the contacting with feedstock producers more difficult. 
The disadvantage of round bales is that they are hard to stack and thus the handling and transport costs are higher. System performance was analyzed and field capacities were determined based on field measurements [16]. Individual handling of bales (either round or rectangular) is not cost effective. The high cost is caused by long loading and unloading times. Multi-bale handling units have been designed, and these units are discussed in Section 9 of this chapter.

\section{Field working days - Harvesting limitations}

Determining the schedule time required for harvest operations is an essential prerequisite to determine herbaceous biomass priority for securing inventory and effectively matching the transport of biomass from SSLs (satellite storage locations) to a biorefinery. Estimating the number of days expected to be available for baling is difficult because agricultural field work is heavily weather dependent and information concerning winter field operations is not well established. Harvest costs depend in part on the investment required in harvest machines (number of machines purchased), and this investment depends on the field capacity of the machines and the number of field workdays available during the harvest window. Therefore, an estimate of the number of harvest days is necessary to determine the total investment in harvest machines required to support a biorefinery.

The optimal perennial grass harvest strategy for a biorefinery remains to be determined. One potential strategy is to delay harvest until the plants standing in the field have transitioned from a non-dormant to a dormant state. Transitional events within the plant include translocation of nutrients from the above-ground plant parts to below-ground plant parts as initiation of degeneration (senescence) of above-ground tissues occur. Delaying harvest until the end of this transitional period, and harvesting over a short time period, can result in near maximum biomass yield, reduced moisture content, and reduced amount of nutrients removed with the biomass. This strategy would suggest an optimum harvest window for switchgrass from October to December. However, a harvest season this short would require substantial investment in harvest machines to complete harvest within a 3month period. It also requires a large storage for inventory to supply the plant for yeararound operation. By delaying harvest until nutrients have translocated, biomass tonnage will be decreased by this loss of mineral content, however since the relative amount of carbon in the material is increased, conversion efficiency and combustion quality may be improved [17]. Moreover, the translocated nutrients stored in the roots can be used for growth and development by the plant year after year, thus, reducing the need for and cost of supplementing the soil with nutrients through fertilization.

A second strategy is to extend harvest over as many months as possible. This would enable more economical use of harvest machines, reduce the quantity required in SSL storage, and potentially better match truck transport with SSL operations. With an extended harvest strategy, harvest would begin in July and extend through the following March. This extended harvest season would allow for spreading the fixed costs of the harvest machines over more $\mathrm{Mg}$ harvested per year thus reducing the $\$ / \mathrm{Mg}$ harvest cost. However, the earlier 
harvests before senescence (July through September) will remove more nutrients, and they will potentially conflict with other farm operations (i.e. grain/hay harvest, small grain seeding). To maintain productivity, additional fertilizer will be required, and this represents an additional cost to the farmer whose fields are harvested prior to October. The farmer whose fields are harvested January through March will have a lower yield because of leaf loss from the standing biomass exposed to winter conditions.

A delayed harvest raises an important issue relative to the payment to a farmgate contract holder. As previously explained, a certain loss occurs when the crop is left standing in the field for delayed harvest (December through March). Also, the delayed harvest increases the risk that a weather event will cause the crop to lodge so the harvest machine leaves material, and the "yield" is reduced. If these same fields were harvested during the optimum window (October through December) and stored longer in an SSL, there is a storage loss that increases with time in storage [18]. Considering the total reliance on stored biomass during the non-harvest months, which strategy is the better choice for the farmgate contract holder (i.e., generates the maximum quantity of biomass to sell to the biorefinery)? Is it better to delay harvest or build a larger SSL and invest in more harvesting machine capacity to complete the entire harvest within the 3-month optimum window? Epplin et al. [19] estimated differences in switchgrass harvest costs for both a 4-month and a 8-month harvest window. They accounted for differences in biomass yield across months, but they did not adjust for fertilizer requirements. They found that the estimated harvest costs varied from $\$ 25$ per $\mathrm{Mg}$ for a 4-month harvest season to \$11 per Mg for a 8-month harvest season. These results show that the length of the harvest season is a significant factor in determining the costs of harvesting biomass.

Epplin et al. [19] did not have refined estimates of the number of days that biomass could be harvested. They based their estimates of available harvest days on a study designed to determine the number of days that farmers in Southwestern Oklahoma of United States could conduct tillage operations. To determine more precise estimates of the number of harvest machines required to harvest, and thus obtain a more precise estimate of harvest costs, a more precise estimate of the number of harvest days is required.

Hwang et al. [20] determined the number of suitable field workdays in which switchgrass could be mowed and the number of days that mowed material can be baled. Empirical distributions of the days available for mowing and for baling switchgrass were determined for nine counties in Oklahoma. Distributions were determined for each month and for two potential harvest seasons (short, October-December and extended, July - February). Several conditions are necessary for safe baling of switchgrass. First, the soil must be sufficiently dry to support the weight of harvest machines. Second, prior to baling, the moisture content of the cut switchgrass must be at a level for safe storage. They provided evidence of the difference in harvest days across strategies.

Determining the time available for required harvest operations is a necessary, but not sufficient, prerequisite for determining the optimal harvest strategy. Additional information will also be required. As previously explained, if harvest begins in July prior to maturity 
and subsequent senescence in October, additional fertilizer will be required (the amounts are undefined) to offset the nutrients removed from the pre-senescence harvest. If harvest is delayed into December or later, the harvestable yield will be less (the amounts are undefined) than if it is harvested in October and November. Thus, the information regarding differences in harvest days across months must be combined with information regarding differences in fertilizer requirements, and biomass yields across harvest months, to determine an optimal harvest strategy.

\section{Constraints for a typical biomass logistics system}

\subsection{Constraints set by resource}

Any biomass crop that provides an extended harvest season has an advantage because most biorefineries want to operate as many hours per year as possible. Continuous operation yields the maximum product per unit of capital investment. Herbaceous crops cannot be harvested during the growing season. Thus, storage is always a component in a singlefeedstock logistics system design.

Two examples are discussed from opposite ends of the length-of-harvest-season spectrum. In the Southeastern United States, wood is harvested year-round. This is referred to as "stored on the stump." Weather conditions in the Southeast are such that few harvest days are lost in the winter due to ice and snow. On the other end of the spectrum, consider the harvest of corn stover in the Upper Midwest of the United States. The grain harvest is completed in the fall, and then the stover is collected. In some years, there are less than 15 days between the completion of the grain harvest and the time when the fields are covered with snow, and no stover can be collected. All feedstock required for year-round operation of a bioenergy plant, if it uses only corn stover, must be harvested in a three- to five-week period. This is a significant challenge for a logistics system.

\subsection{Constraints set by purchaser of raw biomass}

Biorefinery operators are interested in the cost of the feedstock as it enters their plant. The plant can burn the biomass directly to produce heat and power, or it can use the biomass as a feedstock for some more complex conversion processes to produce a high-value product. The term "feedstock" is used to refer to any raw biomass before its chemical structure is modified by a conversion process, which can be direct combustion, thermo-chemical, or biological.

Feedstock cost ( $\$ /$ dry ton) is defined as the cost of the stream of size-reduced material entering the reactor at the Bioenergy plant for 24/7 operation. The reactor is defined as the unit operation where an initial chemical change in the feedstock occurs. The reason for choosing this reference point for the biomass logistics system is two-fold.

1. The plants that can operate continuously, 24/7, have an advantage. Maximum production (tons/y) per unit of capital investment gives a competitive advantage in the market place - cost to produce the product is lower. 
2. Some logistics systems do size reduction with the harvesting machine, while some size reduce at a transfer point between in-field hauling machines and highway hauling machines (perhaps as a pre-requisite to a densification step), and some size reduce at the entrance to the processing plant. In order to compare the several systems, it is necessary to have a consistent end point for the system analysis.

The readers should be aware that many studies in the literature select a different analysis endpoint than used here. A typical endpoint is the cost of feedstock when a truckload of raw biomass enters the plant gate. This reference point is favorable as many agricultural and forest industries pay the producer when the raw material is delivered to the plant.

\section{Field loss}

The yield losses of different herbaceous biomass feedstocks while standing in the field will impact the harvest systems and the windows of opportunities to gather the feedstocks into storage. The inventory losses will be impacted by herbaceous biomass feedstocks, package configurations and integrity, storage facilities and time in storage. Loss of dry matter is also an important parameter in biomass collection and transportation.

Biomass loses dry matter due to its high moisture or dryness. Leaves and other fragile parts of the plant are broken and lost in the wind or mixed with soil. Some of the losses occur during storage due to fermentation and breakdown of carbohydrates to carbon dioxide and other volatiles. Unfortunately the exact account of switchgrass losses in the field or during storage is not available. Sanderson et al. [21] reported dry matter loss in baling and storage of switchgrass and stated that the overall losses were less than for legume hay. They estimated that switchgrass bales stored outside without protection resulted in a dry matter loss of $13 \%$ of the original bale dry weight. They also estimated that dry matter loss of $1-5 \%$ during baling depending on the moisture content. Kumar and Sokhansanj estimated field and storage losses for straw and stover [22]. Other studies have also estimated the dry matter loss of biomass during storage, collection and transport [23-26]. Turhollow [27] estimated the losses from switchgrass to be similar to losses in alfalfa. The study estimated $8 \%$ losses for a mower-conditioner, $3 \%$ for a rake, $10 \%$ for a round baler, and $0.1 \%$ for a round bale wagon. He estimated average loss of $15 \%$ over 6 months of storage. A recent study showed that the dry matter loss in switchgrass collection (including storage) is less than $2 \%$ for different collection methods.

Moisture causes damage (microorganism growth) and subsequent dry matter losses in stored switchgrass bales. Several studies have shown that dry matter losses in switchgrass bales are greater for bales stored outside as compared to bales stored inside [18,22,28]. Moreover, dry matter losses are far greater for covered rectangular bales than uncovered round bales [18]. Large uncovered round bales had a better economic return than covered rectangular bales, when considering the cost due to mass loss during storage [18]. However, another study highlighted their successful use of rectangular bales [29]; the cost of covered storage was more than offset by the reduction in hauling cost for the square bales. 


\section{Computer model of biomass logistics systems}

When a series of operations are linked into a long chain of events, it is often difficult to see which operation is having the most impact on cost-effectiveness. Computer-assisted decision making tools are useful to select the most cost-effective logistics system. Recent studies [30-33] compared a number of different scenarios to determine the best unit operation options and identify bottlenecks. Mathematical programming approaches have been used to develop optimization models that are applicable to a variety of cases studies [34-37]. More recently, focus has shifted to simulation models using object-oriented programming [38] or discrete event simulation [39, 40]. The object-oriented approach [22, 41-43] simplifies scenario building, particularly related to various equipment options available for the same operation, since data pertaining to different options are stored in a standard object-oriented format.

The biomass logistics subject area can be divided into two types of modeling approaches depending on the environment encountered: stochastic or deterministic, and integer or continuous. In the areas of stochastic and deterministic environment, ISBAL and BioFeed capture the stochastic biomass logistics issues such as variability in processing as a result of weather, time, equipment breakdowns, etc. Additional work in this area can be found in [34; 40; 44-45]. In the deterministic environment, most work utilizes a geographic information system (GIS) interactively with optimization. This allows the GIS framework to work as a data management tool, which may call the optimization software directly. Most of the deterministic models are mixed-integer programs [37, 46-49]. One of the principles of designing an effective logistics system is starting with the feedstock resources distribution, and the simplest method is to utilize a GIS framework for data management.

Continuous models assume that all the land within a region is utilized for biomass production [50-52]. This approach uses average haul distances and cost. Hence, the solution obtained is difficult to implement due to lack of detail, as opposed to the solution obtained using an integer model formulation, where each production field is considered as a specific entity with specific costs, thereby resulting in precise decisions for implementation.

\subsection{Modeling of biomass harvesting and handling systems for field operations}

There are numerous studies developing for the optimum set of field equipment where the unit operations affect the performance of units upstream or downstream. Review of this literature is beyond the scope of this chapter. However, several simulation programs are highlighted that specifically addresses a biomass harvest and delivery system.

The Integrated Biomass Supply Analysis and Logistics Model (IBSAL) is a simulation model which simulates operations in the field $[22,38,41]$. ISBAL is very useful for the simulation of operations that collects feedstock from the field and examines the flow of biomass into storage. IBSAL is best used for drawing conclusions about a sequential set of events. For example, if the user has a defined number of fields, a defined set of equipment, and a target number of tons to be harvested each month (each week) then IBSAL can provide valuable 
guidance for optimum biomass collection. The influence of weather, equipment breakdowns, and other disturbances to the biomass system can be "played" with a series of simulations.

The BioFeed model [43] determines the overall system optimum, and integrates the important operations in the biomass chain into a single framework. It is possible that the optimal solution recommended by BioFeed may not be implemented in a real system, either due to unforeseen disturbances such as weather or due to the actions of independent stakeholders such as farmers. However, an integrated model such as Bio-Feed determines the optimal configuration, system bottlenecks, and potential improvements. Such a model can be useful in quantifying the systemic impacts of technology improvement [42].

The BioFeed model results were compared to recent studies in literature $[22,31,33]$. The scope of the BioFeed model was similar to the scenarios developed in [22], where the delivered cost was estimated to be about $\$ 35 / \mathrm{Mg}$ (d.b.) excluding biomass size reduction. The major differences between ISBAL and BioFeed were harvesting and storage costs. While Kumar and Sokhansanj [22] ignored the storage costs, they also considered a self-propelled forage harvester which had a higher throughput capacity than the mower-conditioner considered in BioFeed, thereby reducing the cost. Khanna et al. [31] reported the switchgrass delivered cost of $\$ 64.84 / \mathrm{Mg}$, which was similar to the BioFeed cost estimate. The study by Duffy [33] estimated the delivered cost to be $\$ 124.30 / \mathrm{Mg}$. However, the major difference in the estimates was due to a much higher establishment cost.

Since the scope of the analyses and the assumptions differed for these studies, it is impossible to make specific comparisons. However, these comparisons illustrate that the overall model predictions agree reasonably well.

\subsection{Modeling of biomass delivery systems}

Linear programming models have been used to analyze system interactions in biomass delivery systems. Dunnett et al. [53] proposed a program to optimize scheduling of a biomass supply system for direct combustion. This model simulated storage on farms and delivery to one location with a variable demand for heat. They suggest that costs of biomass handling can be improved 5 to $25 \%$ with the model recommendations. Bruglieri and Liberti proposed a "branch and bound" nonlinear model to determine biorefinery locations as well as the optimum transport method [54]. Their model focused on multiple feedstocks but did not use actual equipment performance data.

A model comprised for multiple purposes can bring attributes of benchmarking, simulation, and linear programming together to solve for the best solution. Leduc et al. a system of wood gasification plants optimized [55]. Their model focused on establishing a biorefinery plant in a location that is suitable for distribution of the product being manufactured (in this case, methanol). Other similar models have focused on silage handling operations [56].

A number of models have proven that a single chain of handling procedures can be optimized, but fail to adequately address the "disconnect" caused by storage, specifically 
satellite storage. Unfortunately, few models consider different harvest systems (or feedstock) supplying a single biorefinery. For example, one equipment system delivers chopped material directly from the field to the plant (probably from fields close to the plant), and a second set of equipment bales material and places it in storage which will be delivered during months when direct delivery of field chopped material is not possible.

As described earlier, a satellite storage location (SSL) is a pre-designated location that is used as a storage location for the biomass collected by the producers within a defined geographic region. SSLs are a logical transition point between "agricultural" and "industrial" operations and thus are critical elements in a logistics system design.

\subsection{Study of Satellite Storage Locations (SSLs)}

An SSL should be established where sufficient feedstock density will ensure the investment is justified. Location affects the costs associated with transporting the biomass from the production field to the SSLs and from the SSLs to the biorefinery. An additional factor that needs to be considered is how often a SSL is filled and unloaded. If a SSL is emptied only once a year, then the total SSL storage area would be doubled as compared to a twice-peryear unload schedule. Note, multiple fillings of a SSL is possible if harvest can be extended over several months and is properly matched with the SSL unload sequence.

Specialized equipment, with high productivity (ton/h) will be utilized to empty each SSL. This equipment can be permanent equipment for each SSL, or the equipment may be mobile and move from one SSL to the next. Questions that need to be answered to implement the mobile option are: 1) how many sets of equipment should be used to service the entire area? 2) What is the sequence of SSLs that each equipment set should unload? 3) Is an SSL ready to be unloaded? This last question directly affects the hauling company's contract. These questions are best considered in a virtual environment where scenarios can be compared and contrasted.

A case study to characterize feedstock resources and establish the SSL's was analyzed by Resop et al. [57] for a 48-km radius around Gretna, VA, USA. The GIS analysis identified potential production fields based on current land utilization determined using aerial photography and landuse classification (Figure 5). The analysis selected fields such that the production area was $6 \%$ of the total land area within the radius. The biomass produced is sufficient to supply the demand for a $1,944 \mathrm{Mg} / \mathrm{d}$ biorefinery, assuming 47 operating weeks per year. SSLs were established at 199 locations, and the existing road network (GIS database) was used to determine the travel distance from each SSL to the proposed plant location in Gretna. A weighted Mg-km parameter for transportation from the SSLs to the plant was computed to be $44.8 \mathrm{~km}$, which implies that, averaged across all 199 SSLs, each $\mathrm{Mg}$ traveled an average of $44.8 \mathrm{~km}$ to the biorefinery.

Judd et al. studied three equipment options for the operations performed at a SSL [58]. Two options utilize the rack concept [59]. Ravula et al. analyzed a round bale logistics system utilizing this rack system; the rack size emulate a $20-\mathrm{ft}(6.1-\mathrm{m})$ ISO container providing two 
levels of 8 bales, total of 16 bales, to be handled as a single unit [40]. A tractor-trailer truck can haul two racks (32 bales, $14.4 \mathrm{Mg}$ ). The results showed the rack hauling had higher transportation costs due to not loading the truck to maximum allowable weight.

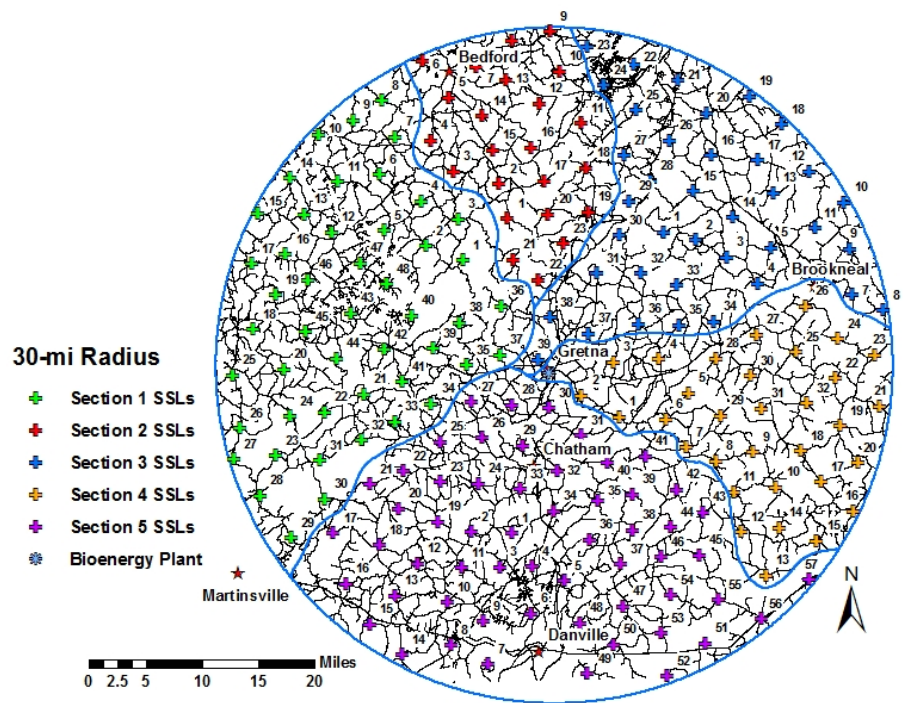

Figure 5. Example of Satellite Storage Locations (SSLs) located over a 30-mi $(48-\mathrm{km})$ radius around a chosen bioenergy location. The refinery is located in the center of the circle. Each cross represents an SSL location with access to the public road system. The smallest SSL was a storage that can store biomass from 60 ac ( 24 ha) of production fields and the largest stores biomass from 1200 ac ( 486 ha) of production fields.

At a SSL, the round bales could be handled in one of two ways. The first option loads bales into the rack from the rear and is referred to as the "rear-loading." The second option, referred to as the "side-loading," loads the bales into a rack from the side. These two options were compared to grinding the bales at the SSL and compacting the ground material into a briquette (maximizes over-the-road load) for delivery [50]. Judd et al. [58] found that it was more cost effective to use the "side-load" option and haul the round bales than to form briquettes at the SSL, if the haul distance was less than 50 miles $(81 \mathrm{~km})$.

The large biorefinery concept calls for delivery of feedstock from a large geographic area. The results [58] suggest that some type of intermediate processing step, referred to as an Advanced Regional Biomass Processing Depot (ARBPD) by Eranki et al. [60], may be needed. These depots will convert the raw biomass to a more energy dense (higher value) product, and this product will then be delivered to a large biorefinery for final processing.

Why was the expense of size reduction and densification into briquettes at the SSL considered? Independent studies [61-63] reported that the tradeoff between the additional cost for densification and the reduction in transportation cost is significant for the hauling of logging residues. For additional work in the area of densification, see [64-65]. 


\subsection{Application of information technologies}

The inclusion of a hauling contractor in the business plan provides the best opportunity for all of the technology developed for other logistics systems to be applied to feedstock logistics. The information technologies applied include a GPS receiver in every truck and a bar code on every load as well as geographic mapping and routing management tools. Thus, time and location information can be observed at every SSL and the weigh-in scale at the receiving facility. The data collected can be used to optimize asset utilization in real time, and it will also feed needed data into the accounting software to compensate the farmgate and haul contracts.

It is expected that the collected data will be presented in real time. The information will provide a "Feedstock Manager," maps showing the location of all assets with updates at suitable time intervals. The goal is to provide an opportunity for the Feedstock Manager to make optimization decisions in real time. Examples are: trucks rerouted to avoid traffic delays, assets redeployed during breakdowns, increase at-plant inventory when inclement weather is forecasted, and a turn-down of plant consumption when a delay in feedstock deliveries cannot be avoided.

Some perspective of the logistics complexity, as presented to the Feedstock Manager, can be gained from the following sample parameters. This example presumes that operations will be in the Upper Southeast of the United States where switchgrass is harvested over an 8month harvest season. Suppose the supply area has 199 SSLs within a 48-km radius of the plant, and each SSL has a different amount of material stored as shown in Figure 6. The producer desires to fill their SSLs at least twice during the harvest season to minimize perMg SSL investment. Suppose there are five SSL crews under contract and each of them wants the same opportunity to earn income (total $\mathrm{Mg}$ mass hauled per year). The Feedstock Manager's job is to treat all farmgate and haul contractors fairly.

\subsection{Benchmarking models for biomass logistics}

It is appropriate to benchmark a proposed feedstock delivery system against existing commercial systems; for example, woodchips, grain, hay, sugarcane, and cotton. Ravula et al. [37] studied delivery to a cotton gin from over 2,100 field locations to better understand logistics system design for a biorefinery.

Switchgrass, corn stover, and other energy crops present two major challenges when benchmarked against other commercial examples. First, energy crops are spread over a greater number of sites when compared with woodchips harvested as byproducts from logging. Second, energy crops have low value when compared with hay, grain, sugarcane, or cotton. Applying benchmarked models to energy crop systems provides a starting point, but optimization techniques must be applied to "fine tune" the logistics system design.

\subsection{Simulation of mixed harvesting options for supply of single plant}

Brownell and Liu [66] developed a computer model to select the best option, or the best combination of options, for supply of a given bioenergy plant. The options include a direct 
chop and delivery option, two bale options (round and large rectangular), and a variation of the large rectangular bale option where these bales are compressed at a stationary location before shipment. Specifically, the options are: (1) loose biomass harvest using a self-loading forage wagon; (2) round bale harvest; (3) large rectangular bale harvest; and (4) large rectangular bale with compression before hauling.

The results of the model provide users a decision matrix which shows the optimized handling scenario for all four handling options analyzed by this program. Cost calculation was based on three plant demands $(2,000,5,000$, and 10,000 Mg DM/d) to compare costs as the required production area expanded. Satellite storage locations were established based on the distribution of production fields and the existing road network.

The key constraints used for the simulation are:

1. Only loose biomass can be directly hauled from the field to the biorefinery.

2. Biomass cannot be stored at the plant, 20,000 tons $(18,144 \mathrm{Mg})$ will "stand in field" in surrounding area of the plant and collected on demand as loose material.

3. Baled biomass will be transported to and stored at satellite storage locations.

4. Large rectangular bales may be compressed before transportation.

5. Biomass will be grown on one third of the available acreage, with an average yield of 3 $\mathrm{Mg} / \mathrm{ha}$ (15\% average moisture content).

The land close to the plant is more valuable, from the biorefinery viewpoint, for the production of feedstock. The study found that a plant can afford to pay more for feedstock (landowner gets a higher price) if a farm happens to be closer to the chosen plant location.

The results showed that the size of SSLs is sensitive to the amount of material demanded by the plant. The program tests various sizes, distances between SSLs, and possible overlaps of production fields "served" by each SSL. The programming optimizes the simulation by slowly changing the size and location of SSLs. The program solves for the maximum amount of acreage available in the simulation model. The output is a distance material in each SSL can be efficiently hauled based on if it is harvested and hauled directly from the field or if it is baled and stored before hauling. The program also solves for the lowest cost for a set acreage when the closest fields are field chopped and remaining fields are baled.

\section{Commercial examples of logistics systems}

\subsection{Typical linkage in logistics chain}

As previously stated, biomass logistics is "a series of unit operations that begin with biomass standing in the field and ends with a stream of size-reduced material entering a bioenergy plant for 24/7 operation." This concept can be visualized as a chain (Figure 6), where the links are unit operations. The example in Figure 6 shows a logistics system moving bales from the field to SSLs, and then from these SSLs to a bioenergy plant. The dotted lines show various segments of the chain that are assigned to the several entities in the business plan. In this example, the segment identified "farmgate" is performed by the 
feedstock producer, the segment labeled "SSL" is performed by a load-haul contractor; the segment identified as "Receiving Facility" is performed by the bioenergy plant. Figure 6 is one example; several other options are used in commercial practice. In next section, three commercial examples are given to show readers the range of options in a logistics system.

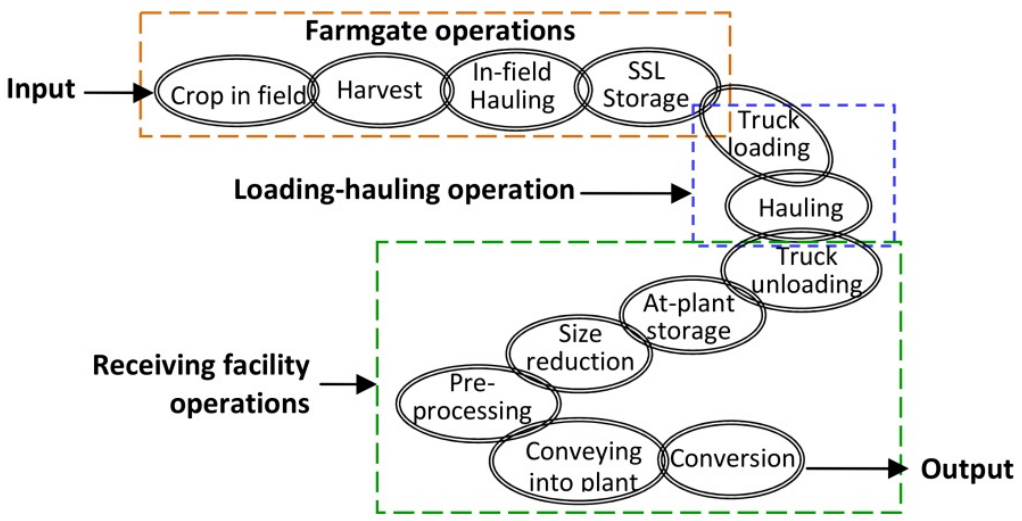

Figure 6. Logistics chain for delivery of round bales to a bioenergy plant (The dotted lines identify segments of the chain which are performed by different business entities).

\subsection{Examples of commercial logistics models}

\subsubsection{Traditional model}

The producer grows, harvests, stores, and delivers raw material (biomass) in accordance with a contract with the processing plant. Deliveries are made to insure the plant has a supply for continuous operation during the processing season. For many agricultural industries (i.e. cotton, grain, sugar cane, fruits and vegetables), the processing season approximately coincides with harvest season, and it is only part of the year.

The advantage of the traditional model, from a processor's point of view, is that all quality issues reside with the producer. There is no question who is responsible if a quality standards are not met. Business people planning the operation of a bioenergy plant tend to prefer this model, though they typically balk at paying a feedstock price that adequately compensates the producer for their additional risk.

\subsubsection{Cotton model}

A cotton producer grows, harvests, and stores the raw material (seed cotton) in modules at an edge-of-field location with suitable access for highway hauling trucks (Figure 7). The gin (processing plant) operates a fleet of trucks to transport the modules as required for operations during the ginning season. Farmers are paid for the seed cotton that crosses the scale at the gin. The gin operates a warehouse and stores bales of ginned cotton for periodic delivery to provide a year-round supply for their textile mill customers. 


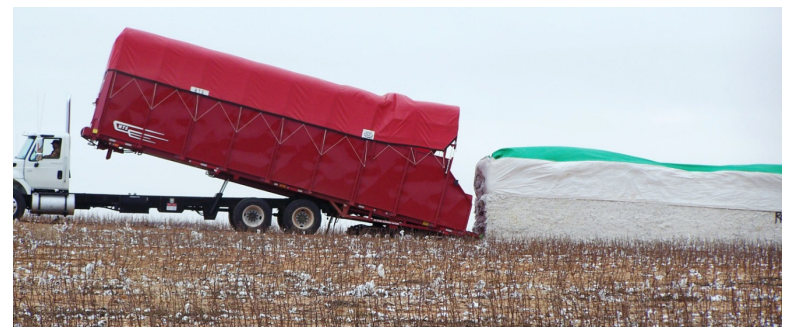

Figure 7. Module hauler picking up module stored at edge of field.

The advantage of the cotton model is that the specialized equipment used for hauling the modules is owned, scheduled, and managed by the gin. Thus, the producer does not own a piece of equipment they will use only a few times a year. The gin deploys the module haulers to their customers, thus the haulers accumulate more hours per years over what a producer would use, and the hauling cost $(\$ / \mathrm{Mg})$ is minimized [40]. Typically, gins haul modules in the order they are "called in" by the producers. Module storage time in the field, and any subsequent losses (at the gin), are not dealt with in the producer-gin contract. The producer is paid the contract price for the mass of cotton fiber (and co-products) that the gin produces from a particular module.

\subsubsection{Sugarcane (Texas model)}

The producer grows the sugarcane. The sugar mill takes ownership of the crop in the field and harvests and transports it for continuous operation during the processing season. Sugarcane must be processed within 24 hours of harvest so storage is not an option within the sugarcane system.

The advantage of the Texas model is that the producer does not own any harvesting or hauling equipment. The disadvantage of the system is the producer does not have control over the time of harvest. Sugar content peaks (point of maximum compensation) in the middle of the season and a producer who has their cane harvested early, or late, sells less sugar. Fortunately, the issue is addressed in their contract.

\section{Development of concept for multi-bale handling unit}

\subsection{Modulization of bales}

Individual handling of bales (round or square) is not cost effective because of long loading and unloading times. Several concepts for a multi-bale handling unit are being developed. A verified multi-bale system is not available at this time to use as an example.

Permission was received [67] to present a concept that is far enough along in development that some field tests have been done. The concept was developed by a consortium led by FDC Enterprises and is shown in Figure 8. The self-loading trailer loads six stacks of six large rectangular bales, referred to "6-packs," for a total load of 36 bales. The bale size is 0.91 
$\mathrm{m} \times 1.22 \mathrm{~m} \times 2.44 \mathrm{~m}$. The length of the load is $6 \times 2.44=14.6 \mathrm{~m}(48 \mathrm{ft})$, the height is $3 \times 0.91=$ $2.74 \mathrm{~m}(9 \mathrm{ft})$, and the width is $2 \times 1.22 \mathrm{~m}=2.44 \mathrm{~m}(8 \mathrm{ft})$.

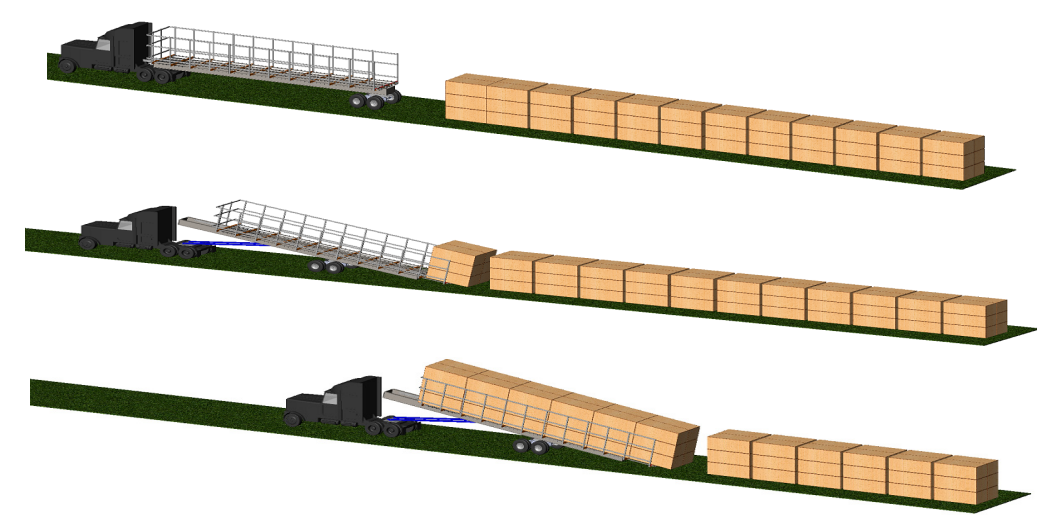

Figure 8. Multi-bale handling unit concept developed for 3x4x8 large rectangular bales by FDC Enterprises-led Consortium (Reprinted with permission [67]).

The trailer built to implement the concept [68] is shown in Figure 9. Estimated load time is 5 min, which is about the same load time for the cotton module (Figure 7). The 36-bale unit can be off-loaded by the truck directly onto the conveyor into a bioenergy plant, or it can be off-loaded into at-plant storage to be used later, just as is done with cotton modules at a cotton gin.

A similar concept known as the "Rack System" envisions that round bales will be loaded into a rack in-field or at an SSL. This rack is lifted off a trailer at the plant, emptied as the bales are needed, and then returned to be refilled. The racks are cycled multiple times each week within the closed logistics system. Cundiff et al. [59] developed the rack system concept, and it will now be used as an example to illustrate how the principles required for a logistics system are implemented.

All the various concepts and options cannot be discussed. However, we will apply a specific example to help the reader think through a process of developing a logistics system. The selection of the "Rack System" for this example implies no criticism of other ways of implementing the multi-bale handling unit concept currently being developed.

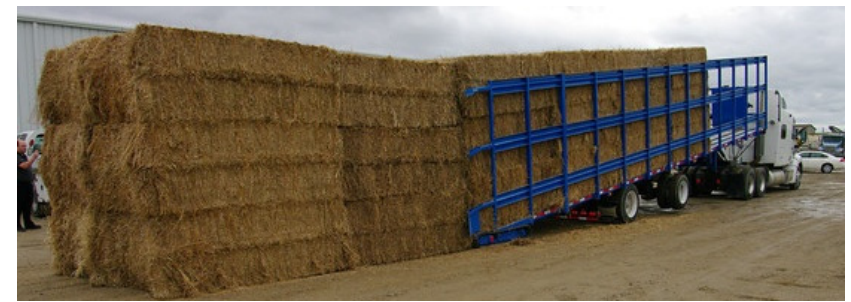

Figure 9. Self-loading trailer built by Kelderman Mfg. to implement multi-bale handling unit concept for 36-bale stack of large rectangular bales. 


\subsubsection{Receiving facility}

When a truckload of feedstock arrives at the bioenergy plant, what happens? Does this material go directly into the plant as in a just-in-time processing model? Or, does it go into some type of at-plant storage? If it goes into at-plant storage, is there an efficient procedure for placing it into storage and retrieving it? All these questions relate directly to the cost of Receiving Facility operations, thus, when a bioenergy plant commissions a logistics system, it first specifies how it wants to receive material. Key questions for a receiving facility are:

1. Do I want each load to be the same size with the truck loaded the same way (i.e. are bales need to be in the same configuration)?

2. What are the hours of operation, and can I schedule approximately the same number of deliveries each hour of the workday?

3. What size at-plant storage must be maintained?

Design of a receiving facility is beyond the scope of this chapter; but, it is hoped that by posing these questions, the reader will begin to think about the constraints that a bioenergy may have when specifying a logistic system. Two criteria used in this example are:

1. Weigh and unload a truck in $10 \mathrm{~min}$, and

2. Cost effective flow of material in-and-out of at-plant storage to support 24/7 operation.

Design of a logistics system is directly linked to the design of the receiving facility - neither is designed independent of the other.

\subsubsection{Farmgate contract}

Creation of a multi-bale handling unit will require specialized equipment. It is not a costeffective to require each farmgate contract holder to own this equipment The rack system, for example, envisions a farmgate contract whereby the contract holder grows the crop, harvests in round bales, and places these bales in storage at a specified SSL. The contract holder owns and maintains the SSL and is paid a storage fee for each unit of feedstock that is stored. The biomass is purchased by the bioenergy plant in the SSL. All agricultural operations are now "sequestered" in the farmgate contract which gives those seeking a farmgate contract a well-defined process to prepare their bid.

A SSL must be graded to a minimum slope specification, must be near a main road, and must have a compacted gravel base. The gravel reduces bale degradation from water damage on the bottom of the bale and provides a suitable surface for equipment operations. Each SSL will receive material from either a single large production field or multiple, smaller fields as proposed by Cundiff et al. [59].

\subsubsection{Hauling contract}

The rack system envisions that the hauling contractor will invest in industrial equipment needed for year-round operation. Because the hauling contractor is hauling year-round, they 
can a) afford to invest in higher capacity industrial-grade equipment designed for up to 5,000 hour/year (or more) operation, and b) their labor force will develop expertise at the operations, and the $\mathrm{Mg}$ handled per unit of equipment investment will be a maximum. These two factors together create the potential to minimize hauling cost $(\$ / \mathrm{Mg})$.

\subsubsection{Storage}

The logistics system has three storage features. Round bale packages act as self-storage and protect the biomass. Rounded top sheds water, so the round bale can be left in the field for a short time before in-field hauling. This provides the advantage of uncoupling the harvest and in-field hauling operations, and thus provides an opportunity for improving the cost efficiency of both operations. The farmgate contract holder has the opportunity to bale when the weather is right and haul later.

The second storage features are the SSLs. These locations provide the needed transition between in-field hauling and highway hauling. The SSLs will be located so that the Mg-km parameter for each SSL will be not more than $4 \mathrm{~km}$. This means that, averaged across all Mgs stored at that SSL, each Mg will be hauled less than $4 \mathrm{~km}$ from the production field to the SSL. This constraint gives the producer an upper bound for calculating in-field hauling cost and all farmgate contractors are treated the same relative to in-field hauling cost.

The third storage feature is the inventory in at-plant storage, which provides the needed feedstock buffer at the plant. Those building a bioenergy plant would like to operate with just-in-time (JIT) delivery of feedstock as this gives them the lowest cost for receiving facility operation. If JIT is not possible, they want the smallest at-plant inventory for cost effective operation. There is obviously a trade-off in the logistics system design between the higher cost to purchase JIT delivery, and the cost of at-plant storage operations.

\subsubsection{At-plant storage}

In day-to-day management, it will be very difficult to achieve JIT delivery of any feedstock for 24/7 operation. All multi-bale handling unit concepts must include some at-plant storage. Even when known quantities of feedstock are stored in a network of SSLs, and a Feedstock Manager is controlling the deliveries, there will be delays.

To give a frame of reference, suppose 3 days of at-plant storage is the design goal. This inventory amount may suffice in the Southeast where ice and snow on the roads is not typically a significant problem for winter operations. But in the Midwest, additional days of at-plant storage will be required. A visualization of 3-day at-plant storage is shown in Figure 10. The number of racks shown is not part of the "cost analysis" example given later.

Bales will remain in the rack until processed; there is no individual bale handling at the plant. This is a very important aspect of any multi-bale handling system. This reduction in bale handling not only reduces cost, but also reduces damage to the bales. The integrity of the bales will be maintained, and bales will have additional protection from the rain since the rack has a top cover. 


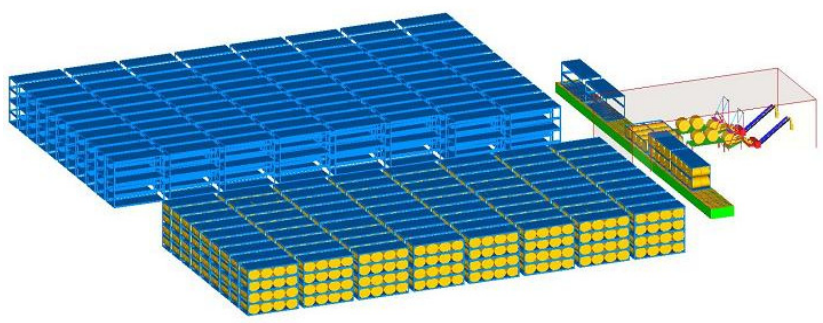

Figure 10. Illustration of at-plant storage for the rack system. At-plant storage shown with 144 racks with bales, 5 racks on conveyor ( 2 full, 1 being emptied, 2 empty), and 176 empty racks.

\subsection{Functionality analysis for rack system concept}

In this example, the analysis begins with round bales in ambient storage in SSLs and ends with a stream of size-reduced material entering the bioenergy plant for 24/7 operation.

\subsubsection{List of baseline constraints}

The constraints for this example are:

1. The rack design, and the design of the trailer to haul the rack, must conform to the standards for highway transport.

2. The rack used for this example holds sixteen $5 \times 4$ round bales. This round bale has a diameter of 1.52-m (5 ft) and a length of 1.22-m $(4 \mathrm{ft})$. With two racks on a truck, a truckload is 32 this kind of round bales.

3. The bales will be pre-loaded into the racks while the trailer is parked at the SSL. When a truck arrives, a trailer with two empty racks is dropped, and the trailer with two full racks is towed away. The goal for the load time (trailer exchange) is $10 \mathrm{~min}$, or less.

4. Hauling of the trailer and racks will be done 24 hours/day. Truck drivers will work five, 8-hour shifts per week and operations will be continuous for a 6-day work week. The rack loading crew at an SSL will be organized such that each worker will work a 40-h week. SSL operations will load bales into racks six 10-h workdays per week.

5. At the Receiving Facility, the racks are lifted from the trailer and placed on a conveyor to be conveyed into the plant for immediate use, or stacked two high in at-plant storage. The goal at the Receiving Facility is for the forklift to lift two full racks from the trailer and replace them with empty racks within of $10 \mathrm{~min}$, or less.

6. The plant will operate with a maximum of 3 days of at-plant storage.

7. The example assumes that the plant processes one bale per minute. Assuming a bale weighs $900 \mathrm{lbs}(0.408 \mathrm{Mg})$ in average (15\% M.C.). The dry mass (DM) per bale is,

$$
0.408 \mathrm{Mg} / \text { bale } \times(1-0.15)=0.3468 \mathrm{Mg} \mathrm{DM} / \text { bale }
$$

Assuming one bale is processed per minute, the processing rate is,

$$
0.33468 \mathrm{Mg} \mathrm{DM} / \text { bale } \times 1 \text { bale } / \mathrm{min} \times 60 \mathrm{~min} / \mathrm{h}=20.8 \mathrm{Mg} \mathrm{DM} / \mathrm{h}
$$


For comparison, $20.8 \mathrm{Mg} \mathrm{DM} / \mathrm{h}$ is $500 \mathrm{Mg} \mathrm{DM} / \mathrm{d}$. This size is in the 100 to $1000 \mathrm{Mg} / \mathrm{d}$ range recommended for Regional Biomass Processing Depots by Eranki et al. [54].

The processing time for racks is:

$$
\frac{60 \mathrm{bale} / \mathrm{h}}{16 \mathrm{bale} / \mathrm{rack}}=3.75 \mathrm{rack} / \mathrm{h}
$$

Thus, the number of truckloads consumed by the plant for a 24/7 operation is,

$$
3.75 \mathrm{rack} / \mathrm{h} \times 24 \mathrm{~h} / \mathrm{d} \times 7 \mathrm{~d} / \mathrm{wk}=630 \mathrm{rack} / \mathrm{wk}=315 \text { truck loads } / \mathrm{wk}
$$

\subsubsection{Operation Plan for 24-h Hauling}

The plant will operate 24/7, but the Receiving Facility will be open 24 hours per day for 6 days. At 6:00 Sunday morning, there will be enough feedstock accumulated in at-plant storage for the maximum 3-day buffer (72 hours). Hauling operations begin again at 6:00 Monday morning. At-plant inventory is decreased to a 2-day buffer (48 hours) to supply the material for operation from 0600 Sunday morning to 6:00 Monday morning.

To discuss the 24-h-hauling concept, it is convenient to consider SSL operations as: 1) "dayhaul" operation, and 2) "night-haul" operations. For the day-haul operation, the racks are transported as they are filled during the day. For the night-haul operation, the required number of empty racks, enough for one day's operation, are pre-positioned at the SSL. Cost of pre-positioning the racks is not considered in this example. The SSL crew fills these racks with bales during their 10-h workday and they are hauled during the night. Each truck arriving during the night unhooks a trailer with two empty racks and hooks up a trailer with two full racks. The next morning, the SSL crew will fill the empty racks delivered during the night and fill them during their workday.

\subsubsection{Operational plan for receiving facility}

A forklift (10-ton or 9.07-Mg capacity) will operate continuously at the receiving facility. This forklift will lift two full racks from the trailer and place them onto a conveyor into the plant for direct processing, or stack these racks in at-plant storage. Then the forklift will lift two empty racks onto the trailer and then the truck returns to the SSL. Empty racks will be stacked in the storage yard until they are lifted onto trailers.

The operational plan calls for two forklifts at the receiving facility, identified as a "work horse" and a "backup." The workhorse will operate continuously and the backup will operate during the day when trucks are waiting in the queue. Key point - the system must have a backup forklift because, if a forklift is not available to lift racks off of and onto trailers, all operations cease.

The handling of the racks emulates the handling of bins at a sugar mill in South Florida. In the bin system, a truck has three bins, two on the first trailer and one on a "pup" trailer. The bins are side-dumped if material is processed directly (Figure 11), or the bins are off-loaded and 
stacked two-high in the storage yard for nighttime operation (Figure 12). When the bins are dumped directly, it takes 3 min to dump the bins. For normal operation, one truck hauls 10 loads (30 bins) a day. At 37 tons/load (33.6 Mg/load), each truck hauls 370 ton/d (336 Mg/d). Sugar cane is $80 \%$ moisture content, so 370 ton $=74$ dry ton/d/truck (67.2 Mg DM/d/truck).

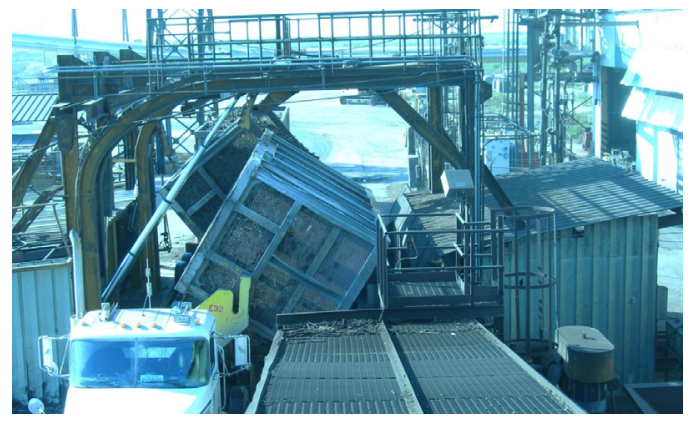

Figure 11. Bins being side-dumped at sugar mill in South Florida, USA.

The conveyor for moving the racks into the plant is an adaptation of a piece of commercial technology. Conveyor design and function is similar to the conveyor used to move cotton modules into a cotton gin. Cotton modules and the 16-bale racks have approximately the same dimensions. The conveyor cost used in the analysis was obtained from a cotton equipment manufacturer. The receiving facility operates $6 \mathrm{~d} / \mathrm{wk}$, thus, on average, the daily delivery will be:

$$
\frac{630 \mathrm{racks} / \mathrm{wk}}{6 \mathrm{~d} / \mathrm{wk}}=105 \mathrm{racks} / \mathrm{d}=53 \text { trucks } / \mathrm{d}
$$

For this example, plant size (23 dry ton/h or $20.9 \mathrm{Mg} \mathrm{DM} / \mathrm{h}$ ) was chosen based on the expected capacity of the two forklifts at the plant. One forklift is expected to lift two full racks and lift and load two empty racks on a trailer at the rate of one truck every 27 minutes averaged over the 24-h a day. The design of the receiving facility and at-plant storage area has to facilitate this operation. A larger at-plant storage area will lower the forklift productivity (ton/h) because the average cycle time to move an individual rack is greater.

\subsubsection{Size of at-plant storage yard}

For example, maximum at-plant storage for a 3-day supply is, 3.75 racks/h times $72 \mathrm{~h}$, or 270 racks. Racks will be stacked two high in "units" with two rows of 24 spaces each (Figure 12), thus there are 48 storage spaces in each unit. Each unit stores 96 racks. Three units are required for 270-racks storage.

$$
3.75 \text { racks } / h \quad x \quad 72 h=270 \text { racks }
$$

If 7-day at-plant storage is required, the total number of racks increases to 630 racks, or seven 96-rack units as shown in Figure 14. This implementation of a 7-day supply is not 
believed to be a cost effective choice, not only because of the capital investment in the racks, but also because of the forklift operating time required to cycle back and forth over a storage area this large. This is a key issue---the larger the at-plant storage, the lower the forklift productivity (ton/h), and thus the higher the forklift cost (\$/ton).

The rack system competes best when the racks are filled and emptied as many times as possible in a given time period, not when they act as storage units. Other multi-bale handling units are more suitable for a larger at-plant storage like the one shown in Figure 14.

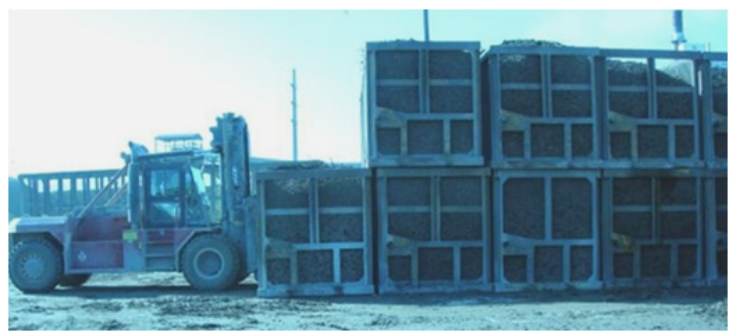

Figure 12. Bins being stacked in at-plant storage at sugar mill in South Florida, USA.

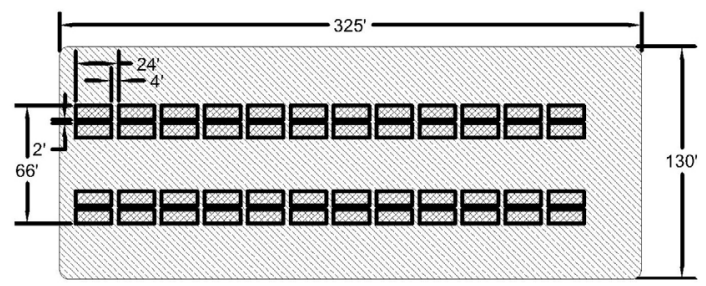

Figure 13. Sample layout of at-plant storage showing a unit (48 storage spaces). Racks are stacked two high for a total capacity of 96 racks (Total area required is approximately $4047 \mathrm{~m}^{2}$ ).

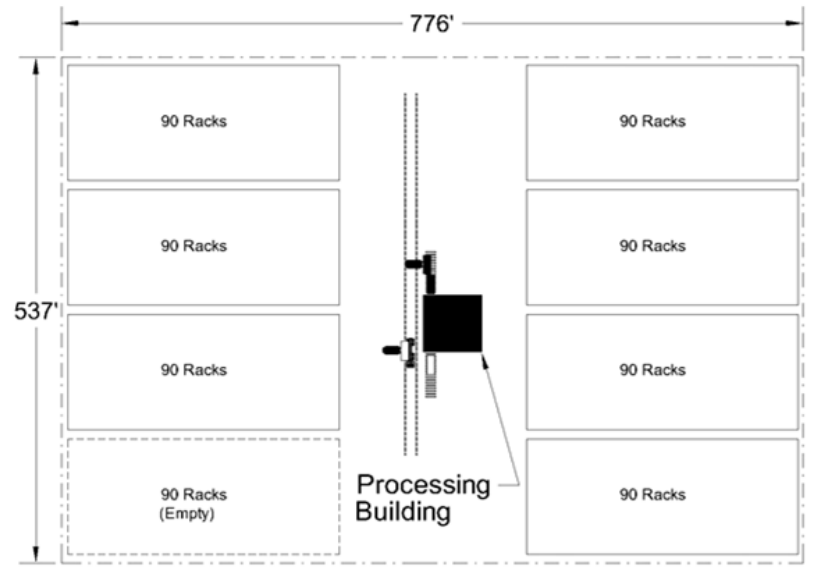

Figure 14. Sample layout of at-plant storage showing a 7-day supply of full racks and space for storing one unit of empty racks. (Total area required is approximately $38445 \mathrm{~m}^{2}$ ). 


\subsubsection{Bale loading into racks at the SSL}

Ideally, the bale- loading- into- racks operation at the SSL should be able to load 16 bales in a rack in 20 minutes. This design criterion has not been attained with actual equipment.

For a workday with 10 productive hours (600 $\mathrm{min})$, a 20-min-per-rack operation can theoretically load 30 racks, or 15 truckloads. Given the reality of SSL conditions, an actual operation could not sustain this productivity. In this analysis, it is reasonable to assume that a mature operation can average $70 \%$ of the theoretical productivity. The number of loadsday-operation used for this analysis will be reduced to $15 \times 0.7=10.5$ loads/d. The number of individual SSL operations required is 315 loads per week, divided by 6-day SSL operation per week, which is 52.5 or 53 loads per day average operation. This is five operations averaging 10.5 loads per day.

Thus, loading operations will occur at five different SSLs with a different set of equipment for each operation. Each SSL operation will load an average of 21 racks per day. Time to move the crew, equipment and reposition the empty trailer/rack from one SSL to the next is not dealt with in this analysis. Thus, the 21 racks/d productivity may be optimistic.

There are several options to load the rack. The option which found to be the most cost effective is the "side-load" option [58]. A telehandler with special attachment can pick up two bales per cycle (Figure 15) and load these bales into the side of the rack. Assuming that the average productivity to be achieved under production conditions is 34 min per rack, then the time needed to load two racks on a trailer is $68 \mathrm{~min}$. Remember, this is the assumed average load time for year-round operation.

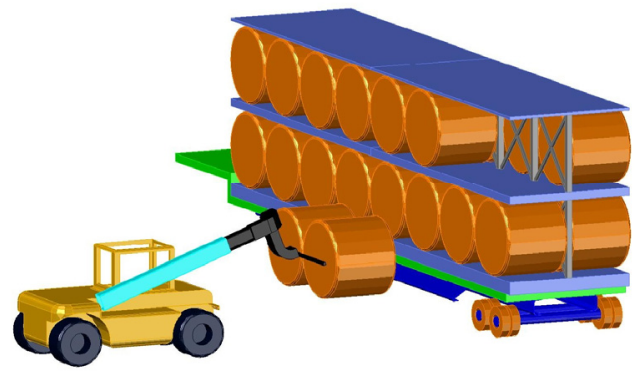

Figure 15. Concept for side loading bales into rack on trailer.

At the SSL, loading of the racks is the most challenging design for a cost-effective biomass logistics system. It is difficult to reduce the cost of these operations because the labor productivity (tons handled per worker-hour) might be low. By uncoupling the SSL loading and highway hauling, the truck does not have to wait for racks to be loaded in order to pick up the trailer. Also, the SSL crew does not have to wait for a truck to arrive with empty racks. However, the hooking/unhooking of trailers may be problematic for some drivers.

The day-haul operations are uncoupled by providing two extra trailers at the "day haul" SSL, and the night-haul operations are uncoupled by providing 9 extra trailers for the "night 
haul' SSL. Each truck tractor then has 11 extra trailers (22 racks) in the system. This may not be a best (least cost) approach, but it does provide a reasonable starting point.

\subsubsection{Influence of SSL Size on Rack Loading Operations}

If the yield of switchgrass in a commercial-scale operation averages 4 ton/ac $(8.96 \mathrm{Mg} / \mathrm{ha})$, this equates to approximately 9 bales/ac ( 22 bales/ha). It is suggested that the minimum size of a SSL contain the bales from 60 ac ( $24.5 \mathrm{ha}$ ) is 540 bales, and the maximum size SSL approximately stores bales from 1,200 ac (487 ha) 10,800. If $70 \%$ of the theoretical loading (30 racks/d) is achievable, the contactor will load 21 racks times 16 bales/rack is equal to 336 bales per day. The minimum size SSL will remove all of the bales in about 540/336, which is 1.6 days. The maximum size SSL will be loaded out in 10,800/336 = 32 days.

Cost of SSL operations at the smaller SSLs will be higher because of the mobilization charge to move equipment and crew to the next SSL for a fewer days of operation. It is probable that the load-haul contract offered by the biorefinery for each individual SSL will consider the haul distance and SSL size and thus the per-ton price will be different for each SSL.

\subsubsection{Total Trucks Required - 24-h Hauling}

To achieve 24-h hauling, the truck drivers will work 8-h shifts and the trucks will run continuously from 0600 Monday to 0600 Sunday, a total of $144 \mathrm{~h} / \mathrm{wk}$. The total racks processed each week are 630, equal to 315 truckloads. If a uniform delivery is assumed, the average truck unload time is,

\section{5 trucks $/ 144 \mathrm{~h}=2.2$ trucks $/ \mathrm{h}=1$ truck $/ 27 \mathrm{~min}$.}

This productivity is well within the Rack System design goal of a 10 min unload time. As previously stated, the 24-h hauling concept envisions that the SSL crew will leave a supply of loaded racks on trailers at the SSL when they finish their 10-h workday. These racks will be hauled during the night. The next morning, the loading crew will load empty racks delivered during the night and load them during their workday.

The key variable in hauling is the truck cycle time. To calculate cycle time, for example, an average haul distance is needed. An actual database was developed for a proposed bioenergy plant location at Gretna, Virginia, USA to calculate the average haul distance.

An analysis was done for a 30-mi $(48 \mathrm{~km})$ radius around Gretna to identify potential production fields based on current land use determined from current aerial photography and GIS methods. It is conservatively assumed that $5 \%$ of the total land was assigned into switchgrass production. SSLs were established at 199 locations (Figure 5), and the existing road network was used to determine the travel distance from each SSL to the proposed plant location at Gretna. Some loads were hauled 2 miles $(3.2 \mathrm{~km})$ and some were hauled over 40 miles $(64 \mathrm{~km})$. A weighted ton-mi parameter was computed and found to be 25.4 miles $(40.6 \mathrm{~km})$. This means that, across all 199 SSLs, each ton travels an average of 25.4 miles $(40.6 \mathrm{~km})$ to get to the plant. 
Truck cycle time is calculated using the 25.4-mile average haul distance, a $45 \mathrm{mph}$ average speed, 10-min to hook/unhook trailers a SSL, and 10-min to lift full and empty racks from the trailers. Theoretical cycle time is $1.46 \mathrm{~h}$. In 24 hours of operation, one truck can haul:

$$
24 h /(1.46 h / \text { load })=16.4 \text { loads per truck per day }
$$

Assuming that a truck fleet can average $70 \%$ of the theoretical capacity, then $(0.7 \times 16.4=11.5$ loads per truck per day can be achieved. Remember, since the trucks run continuously, a decimal number of loads can be used as the average achieved per-day of productivity.

It is not practical to use the each-haul contractor-runs-their-own-trucks assumption for 24-h hauling. The way to maximize truck fleet productivity is to have the Feedstock Manager have the control to send any truck to any SSL where a trailer with full racks is available. This greatly facilitates the hauling at both day-haul and night-haul SSLs.

Total trucks being controlled by the Feedstock Manager is:

53 loads / day required at the plant / 11.5 loads per truck $=4.6$ trucks ( 5 trucks)

Since five SSL crews, one per SSL, are loading trailers/racks. More realistic is that eight to ten trucks will be available and some would also have responsible for bring other supplies to the biorefinery or hauling waste and other value-added products from the biorefinery.

\subsubsection{Total Racks and Assets Required for 24-h Hauling}

Since the only time deliveries are not being made is the 24-h period from 0600 Sunday to 0600 Monday, the amount in at-plant storage can be reduced. Using 1.5 days as the minimum at-plant storage, so the total capacity hours required in at-plant storage at 0600 Sunday, when deliveries are ended for the week, is

$$
\begin{aligned}
24 h(\text { actual })+ & 1.5 d \times 24 h / d(\text { at-plant storage })=60 \text { hours } \\
& 3.75 \text { racks } / h \times 60 h=225 \text { racks }
\end{aligned}
$$

Total trailers are calculated as follows. Each truck has one trailer connected, two parked at a "day-haul" SSL and nine parked at a "night-haul" SSL for a total of 12 trailers. The total racks on trailers are calculated as:

$$
5 \text { trucks } \times 12 \text { trailers per truck } \times 2 \text { racks } / \text { trailer }=120 \text { racks }
$$

Total racks required are:

\begin{tabular}{ccccccc} 
At-plant & + & On 60 trailers & + & Reserve & $=$ & Total \\
\hline 225 & + & 120 & + & 5 & $=$ & 350
\end{tabular}

The actual number of racks required is calculated by subtracting the racks on parked trailers from the rack total (empty + loaded) at the plant. Potentially, 60 loaded trailers can 
be parked at the receiving facility when hauling ends for the week at 0600 Sunday. In order for this procedure to work, the racks on most of these 60 trailers have to be returned to SSLs during the period 0600 Sunday to 0600 Monday so they will be in position for operations to begin at each SSL at 0600 Monday. This requires some empty back hauls. Cost for these empty back hauls is a level of detail that must wait for a more sophisticated analysis.

When racks on trailers are counted as part of the at-plant storage, the minimum number of racks is:

\begin{tabular}{ccccccc} 
At-plant & + & On 60 trailers & + & Reserve & $=$ & Total \\
\hline$(225-120)$ & + & 120 & + & 5 & $=$ & 230
\end{tabular}

Average number of cycles per rack is 29,610 racks processed per year divided by 230 , that is 129 cycles per year; or about 2.7 cycles per week for 47 weeks of annual operation.

\subsection{Cost analysis for $24-\mathrm{h}$ hauling using rack system}

The costs given in this section are presented without supporting detail. They were calculated using the procedures given in [69]. They are "best estimates" given current cost parameters. All costs are given on a $\$ / \mathrm{Mg}$ DM basis for operation of a bioenergy plant consuming 23 dry ton/h $(20.9 \mathrm{Mg} \mathrm{DM} / \mathrm{h})$. The challenge is to find a way that machine productivity $(\mathrm{Mg} / \mathrm{h})$ can be increased.

\subsubsection{Total truck cost}

The assumed truck cost (tractor and trailer for hauling the two racks) is $\$ 630 / \mathrm{d}$ for a $24-\mathrm{h}$ workday, which includes ownership plus operating cost, plus labor, but excluding fuel.

Truck cost, excluding fuel, is:

$$
\frac{\$ 630 / \mathrm{d}}{11.5 \text { loads } / \mathrm{d} \times 12.2 \text { dry ton } / \text { load }}=\$ 4.49 / \text { dry ton }=\$ 4.95 / \mathrm{Mg} \mathrm{DM}
$$

Truck fuel cost for the 25.4 miles $(40.6 \mathrm{~km})$ average haul distance is:

$$
\begin{gathered}
(25.4 \mathrm{mi} \times 2) / 4 \mathrm{mi} / \mathrm{gal}=12.7 \mathrm{gal} \times \$ 3.50 / \mathrm{gal}=\$ 44.45 / \text { load } \\
\$ 44.45 / \mathrm{load} / 12.2 \mathrm{dry} \text { ton } / \text { load }=\$ 3.64 / \mathrm{dry} \text { ton }(\$ 4.01 / \mathrm{Mg} \mathrm{DM})
\end{gathered}
$$

Total truck cost is ownership and operating plus fuel, that is 4.95 plus $4.01=\$ 8.96 / \mathrm{Mg} \mathrm{DM}$.

\subsubsection{Load, unload operations}

1. Handling racks at plant: $\$ 1.93$ (forklift) $+\$ 1.02$ (backup forklift) $=\$ 2.95 /$ dry ton

2. SSL operation: $\$ 3.66$ (telehandler) $+\$ 0.98$ (extra trailers) $=\$ 4.64 /$ dry ton

3. Rack cost: cost for 230 racks $=\$ 1.80 /$ dry ton 
4. Storage yard at processing plant: $\$ 0.13 /$ dry ton

5. Conveyor entering plant: $\$ 0.28 /$ dry ton

(Note: 1 dry ton $=0.907 \mathrm{Mg} D M$ )

\subsubsection{Size Reduction}

1. Unroller-chopper cost: $\$ 5.76 /$ dry ton.

2. Rack cost: all costs associated with the ownership and maintenance of the racks.

3. Loading cost: all costs associated with the loading of bales into racks. These costs are referred to as "SSL operation costs".

4. Truck cost: all costs associated with the ownership and operation of the trucks.

5. Receiving Facility cost: all costs associated with the unloading of racks from trucks, placement of racks onto conveyor (or placement in at-plant storage), conveyor operation, operation of at-plant storage, and removal of racks from at-plant storage and placement on trucks for return to SSL.

6. Size reduction: all costs associated with the unloading of bales from the rack, operation of conveyor for single file bales delivered to size reduction machine, and operation of machine for initial size reduction.

Truck cost is $34 \%$ of the total cost, SSL operations are $20 \%$, Receiving Facility operations are $14 \%$, size reduction is $24 \%$, and the racks are $8 \%$. It is clear why the Rack System Concept was organized to maximize truck productivity; truck cost is the largest cost component. Truck cost plus SSL operations are $\$ 12.77 /$ dry ton, or $54 \%$ of total cost. The Receiving Facility cost is $\$ 3.37 /$ dry ton, only $14 \%$ of total cost. As with all other multi-bale handling system concepts, the Rack System provides an opportunity for minimizing cost between the plant gate and the size reduction unit operation.

The total cost shown in Table 2 does not include the farmgate contract cost (production, harvesting, in-field transport, storage in SSL, and profit to producer). The farmgate contract cost can be estimated from local data for production, harvest, and ambient storage of round bales of hay. In the Southeast the key issue relative to the hay cost comparison is the difference in yield; switchgrass will yield about $9 \mathrm{Mg} / \mathrm{ha}$ as compared to traditional hay species that yield about $4.5 \mathrm{Mg} / \mathrm{ha}$.

\begin{tabular}{lc}
\hline Operation & Cost $(\$ /$ dry ton) \\
\hline Racks & 1.80 \\
\hline Loading at SSL & 3.66 \\
\hline Telehandler & 0.98 \\
\hline Extra Drop-deck Trailers & 8.13 \\
\hline Truck cost & 1.93 \\
\hline Unloading at plant & 1.02 \\
\hline Workhorse forklift & 0.13 \\
\hline Backup forklift & \\
\hline At-plant storage (Gravel lot with lighting) & \\
\hline
\end{tabular}




\begin{tabular}{lc}
\hline Operation & Cost (\$/dry ton)* \\
\hline Conveyor into plant & 0.28 \\
\hline Unroller-chopper (Initial size reduction) & 5.76 \\
\hline Total & $\$ 23.69$ \\
\hline
\end{tabular}

* $\$ 1 /$ dry ton $=\$ 1.103 / \mathrm{Mg}$ DM

Table 2. Total cost for hauling, receiving facility operations, and size reduction for rack system example - side-load option, 24-h hauling.

\section{Conclusions}

The key decision points for the design of a logistics system for a bioenergy plant operating 24/7 year-round are summarized as follows.

1. A complete logistics system is defined as one that begins with the biomass standing in the field and ends with a stream of size-reduced material entering a bioenergy plant for 24/7 operation. Optimizing one unit operation in isolation may increase the cost of an "upstream" or "downstream" operation such that total delivered cost is increased.

2. Most feedstock is harvested only part of the year, thus storage is a part of the logistics system. A cost effective logistics system provides for efficient flow of material in and out of storage.

3. Just-in-time (JIT) delivery of feedstock provides for a minimum at-plant storage cost. Since JIT delivery is not practical for typical biomass logistics systems, there is always a cost trade-off between the size of at-plant storage and the other design constraints needed to insure a continuous feedstock supply. Knowledge of quantities of biomass in Satellite Storage Locations (SSLs) provides the Feedstock Manager at a bioenergy plant an opportunity to minimize the at-plant storage cost.

4. Farmgate contracts that require a summer-early fall harvest must compensate for the removal of nutrients, and contracts that require a winter harvest must compensate for loss of yield incurred by the delayed harvest.

5. Assigning different unit operations to different entities in the business plan can lower average delivered cost. For example, it is more efficient to pool all farmgate activities into a farmgate contract and have a hauling contractor handle all load-haul activities. This division is defined as a division between "agricultural" and "industrial" operations. The key benefit achieved is in the capitalization of the equipment. Loadhaul contractors can afford to invest in industrial-grade, high-capacity equipment designed for year-round operation as compared to farmgate contractors who will use their equipment 400 hours (or less) per year.

6. Uncoupling of the unit operations in the logistics chain can provide an advantage.

a. In the agricultural operations, baling uncouples the harvesting and in-field hauling operations. When the harvesting operation is not constrained by in-field hauling--both unit operations can proceed at maximum productivity. 
b. In the industrial operations, it is important to uncouple truck loading from hauling. Maximum loads-per-day-per-truck are achieved when the loading crew never has to wait for a truck to arrive and the truck never has to wait to be loaded.

7. Truck cost is the largest component of total cost in most logistics systems, thus it is essential to maximize truck productivity ( $\mathrm{Mg}$ hauled per unit time) by increasing both Mg-per-load and loads-per-day. A 10-min load time and a 10-min unload time is a desired goal for design of most logistic systems.

8. Multi-bale handling units are in need to solve the rapid loading/unloading challenge.

9. Twenty-four-hour hauling can minimize truck cost $(\$ / \mathrm{Mg})$. The challenge is to design a logistics system with a practical procedure for loading trucks at night at a remote location.

10. The design of the Receiving Facility, because of the need to unload trucks quickly, is critical in the design of a complete logistics system. Typically, this design specifies that each load have the same configuration, and requires a delivery schedule where approximately the same number of loads is received each workday.

11. The most cost-effective logistics system will be structured such that information technologies (GPS, bar codes, entry of data over cell phone network) and optimization routines developed for other logistics systems can be used to optimize asset utilization in real time.

\section{Author details}

Jude Liu*

Department of Agricultural and Biological Engineering, The Pennsylvania State University, University Park, Pennsylvania, USA

Robert Grisso and John Cundiff

Department of Biological Systems Engineering, Virginia Tech, Blacksburg, Virginia, USA

\section{References}

[1] Brownell D K, Liu J, Hilton J W, Richard T L, Cauffman G R, and MacAfee B R (2009) Evaluation of two forage harvesting systems for herbaceous biomass harvesting. ASABE Paper No. 097390, St. Joseph, MI: ASABE.

[2] Reynolds S G, and Frame J (2005) Grasslands: Developments, opportunities, perspectives. Enfield, New Hampshire: Science Publ. Inc.

[3] Cundiff J S, and Grisso R D (2008) Containerized handling to minimize hauling cost of herbaceous biomass. Biomass \& Bioenergy 32(4): 308-313

[4] Hierden E V (1999) Apparatus for processing large square hay bales into smaller recompressed Bales. U.S. Patent No. 6339986.

\footnotetext{
${ }^{*}$ Corresponding Author
} 
[5] Steffen Systems (2009) High Density Bale Compression Systems. Available at: http://www.steffensystems.com/Products/Bale_Press/index.htm. Accessed 2012 April 19.

[6] Sokhansanj S, Turholow A F, Stephen J, Stumborg M, Fenton J and Mani S (2008) Analysis of five simulated straw harvest scenarios. Can. Biosys. Eng. 50:2.27-2.35

[7] Sokhansanj S, Turhollow A F and Wilkerson E G (2008) Development of the Integrated Biomass Supply Analysis and Logistics Model (IBSAL). Technical Memorandum ORNL/TM-2006/57. Oak Ridge, TN: Oak Ridge National Laboratory.

[8] Kumar, P.K., and K.E. Ileleji. 2009. Tech-no-economic analysis of the transportation, storage, and handling requirements for supplying lignocellulosic biomass feedstocks for ethanol production. ASABE Paper No. 097427, St. Joseph, MI: ASABE.

[9] Brownell D K (2010) Analysis of biomass harvest, handling, and computer modeling. M.S. Thesis. The Pennsylvania State University, University Park, PA.

[10] Srivastava A K, Carroll E G, Rohrbach R P, and Buchmaster D R (2006) Engineering principles of Agricultural Machines. American Society of Agricultural and Biological Engineers, St. Joseph, MI: ASABE.

[11] Cundiff J S, Grisso R D, and McCullough D (2011) Comparison of bale operations for smaller production fields in the Southeast. ASABE Paper No. 1110922. St. Joseph, MI: ASABE.

[12] ASAE Standards D497.5 (2006) Agricultural machinery management data. American Society of Agricultural Engineers, St. Joseph, MI: ASAE.

[13] Liu J and Kemmerer B (2011) Field performance analysis of a tractor and a large square baler. SAE Technical Paper 2011-01-2302, Presented at Commercial Vehicle Engineering Congress, Chicago, IL doi:10.4271/2011-01-2302.

[14] Kemmerer B, and Liu J (2012) Large square baling and bale handling efficiency - A case study. Ag. Sci. 3(2):178-183.

[15] ASAE Standards EP496.3 (2006) Agricultural machinery management. American Society of Agricultural Engineers, St. Joseph, MI: ASABE.

[16] Cundiff J S, Fike J H, Parrish D J, and Alwang J (2009) Logistic constraints in developing dedicated large-scale bioenergy systems in the Southeastern United States. Journal of Environmental Engineering-ASCE 135(11):1086-1096.

[17] Hadders G, and Olsson R (1997) Harvest of grass for combustion in late summer and in spring. Biomass Bioenergy 12(3):171-175.

[18] Larson J A, Mooney D F, English B C, and Tyler D D (2010) Cost analysis of alternative harvest and storage methods for switchgrass in the Southeastern U.S. 2010 Annual Meeting of Southern Agricultural Economics Association, Feb. 6-9, 2010, Orlando, FL.

[19] Epplin F M, Mapemba L, and Tembo G (2005) Economic modeling of a lignocellulosic biomass biorefining industry. In: Outlaw JL, Collins $\mathrm{KJ}$, Duffield JA, editors. Agriculture as a producer and consumer of energy. London: CABI Publishing; 2005. p. 205-217. 
[20] Hwang S, Epplin F M, Lee B, and Huhnke R (2009) A probabilistic estimate of the frequency of mowing and baling days available in Oklahoma USA for the harvest of switchgrass for use in biorefineries. Biomass Bioenergy 33(8):1037-1045.

[21] Sanderson M A, Egg R P, and Wiselogel A E (1997) Biomass losses during harvest and storage of switchgrass. Biomass Bioenergy 12(2):107-114.

[22] Kumar A, and Sokhansanj S (2007) Switchgrass (Panicum vigratum, L.) delivery to a biorefinery using integrated biomass supply analysis and logistics (IBSAL) model. Bioresource Technology 98, 1033-1044.

[23] Rees D V H (1982) A discussion of the sources of dry matter loss during the process of haymaking. J. of Agric. Engng Res. 27:469-479.

[24] Coble C G, and Egg R (1987) Dry matter losses during hay production and storage of sweet sorghum used for methane production. Biomass 14:209-217.

[25] Bledsoe B L, and Bales B M (1992) Bale wrap evaluation. ASAE Paper No. 921573. St. Joseph, MI: ASAE.

[26] LaFlamme L F (1989) Effects of storage conditions for large round bales on quality of grass-legume hay. Can. J. of Animal Sci. 69:955-961.

[27] Turhollow A (1994) The economics of energy crop production. Biomass Bioenergy 6(3):229-241.

[28] Shinners K J, Boettcher G C, Muck R E, Wiemer P J, and Casler M D (2010) Harvest and storage of two perennial grasses as biomass feedstocks. Trans. of ASABE 53(2):359-370

[29] Chariton Valley RC\&D (2002) Chariton Valley Biomass Project - Draft Fuel Supply Plan, United States Department of Energy, Contract Number: DE-FC36-96GO10148

[30] Styles D, Thorne F, and Jones M B (2008) Energy crops in Ireland: an economic comparison of willow and Miscanthus production with conventional farming systems. Biomass Bioenergy 32(5):407-421.

[31] Khanna M, Dhungana B, and Clifton-Brown J (2008) Costs of producing Miscanthus and switchgrass for bioenergy in Illinois. Biomass Bioenergy 32(6):482-493.

[32] Monti A, Fazio S, Lychnaras V, Soldatos P, and Venturi G (2007). A full economic analysis of switchgrass under different scenarios in Italy estimated by BEE model. Biomass Bioenergy 31(4):177-185.

[33] Duffy M (2007) Estimated costs for production, storage and transportation of switchgrass. Ames, IA: Iowa State University, Extension Report No. PM 2042.

[34] De Mol R M, Jogems M A H, Van Beek P, and Gigler J K (1997) Simulation and optimization of the logistics of biomass fuel collection. Neth J Agric Sci 45:219-228.

[35] Cundiff J, Dias N, and Sherali H D (1997) A linear programming approach for designing a herbaceous biomass delivery system. Bioresource Technology 59:47-55.

[36] Zuo M, Kuo W, and McRoberts K L (1991) Application of mathematical programming to a large-scale agricultural production and distribution system. J Oper Res Soc 42(8):639-648. 
[37] Mapemba L D, Epplin F M, Huhnke R L, and Taliaferro C M (2008) Herbaceous plant biomass harvest and delivery cost with harvest segmented by month and number of harvest machines endogenously determined. Biomass Bioenergy 32(11):1016-1027.

[38] Kumar A, Sokhansanj S, and Flynn P C (2006) Development of a multicriteria assessment model for ranking biomass feedstock collection and transportation systems. Appl Biochem Biotechnol 129-132:71-87.

[39] Mukunda A, Ileleji K E, and Wan H (2006) Simulation of corn stover logistics from onfarm storage to an ethanol plant. ASABE Paper No. 066177, St. Joseph, MI: ASABE.

[40] Ravula P P, Grisso R D, and Cundiff J S (2008) Cotton logistics as a model for a biomass transportation system. Biomass \& Bioenergy 32(4):314-325.

[41] Sokhansanj S, Kumar A, and Turhollow A F (2006) Development and implementation of integrated biomass supply analysis and logistics model (IBSAL). Biomass Bioenergy 30:838-847.

[42] Shastri Y, Hansen A, Rodriguez L, and Ting K C (2011) Optimization of Miscanthus harvesting and handling as an energy crop: BioFeed model application. Biol Eng 3(1):37-69.

[43] Shastri Y, Hansen A, Rodriguez L, and Ting K C (2011) Development and application of BioFeed model for optimization of herbaceous biomass feedstock production. Biomass Bioenergy 35:2961-2974.

[44] Gallis C T (1996) Activity oriented stochastic computer simulation of forest biomass logistics in Greece. Biomass Bioenergy 10:377-382.

[45] Nilsson D (2000) Dynamic simulation of straw harvesting systems: influence of climatic, geographical and biological factors on performance and costs. J. Agric. Engng Res 76:2736.

[46] Freppaz D, Minciardi R, Robba M, Rovatti M, Sacile R, and Taramasso A (2004) Optimizing forest biomass exploitation for energy supply at a regional level. Biomass Bioenergy 26:15-25.

[47] Judd J D, Sarin S C, Cundiff J S, and Grisso R D (2010) Cost analysis of a biomass logistics system. ASABE Paper No. 1110466. St. Joseph, MI: ASABE.

[48] Tatsiopoulos I, and Tolis A (2003) Economic aspects of the cotton-stalk biomass logistics and comparison of supply chain methods. Biomass Bioenergy 24:199-214.

[49] Tembo G, Epplin F M, and Huhnke R L (2003) Integrative investment appraisal of a lignocellulosic biomass-to-ethanol industry. J. Agric. Res. Econ. 28:611-633.

[50] Morey V R, Kaliyan N, Tiffany D G, and Schmidt D R (2010) A corn stover supply logistics system. Applied Eng. in Agric. 26(3):455-461.

[51] Nagel J (2000) Determination of an economic energy supply structure based on biomass using a mixed-integer linear optimization model. Ecol. Engng 16:91-102.

[52] Gan J, and Smith C T (2011) Optimal plant size and feedstock supply radius: A modeling approach to minimize bioenergy production costs. Biomass Bioenergy 35(8):3350-3359. 
[53] Dunnett A, Agjiman C, and Shah N (2007) Biomass to heat supply chains applications of process optimization. Transactions Institution of Chemical Engineers: Process Safety and Environmental Protection 85(B5): 419-429.

[54] Bruglieri M, and Liberti L (2008) Optimal running and planning of a biomass-based energy production process. Energy Policy 36(7):2430-2438.

[55] Leduc S, Schwab D, Dotzauer E, Schmid E, and Obersteiner M (2008) Optimal location of wood gasification plants for methanol production with heat recovery. Int'l J. of Energy Res. 32(12):1080-1091.

[56] Berruto R, and Busato P (2008) System approach to biomass harvest operations: simulation modeling and linear programming for logistic design. ASABE Paper No. 084565, St. Joseph, MI: ASABE.

[57] Resop J P, Cundiff J S, and Heatwole C D (2010) Spatial analysis to site satellite storage locations for herbaceous biomass in the Piedmont of the Southeast. Applied Eng. Agric. 27(1): 25-32.

[58] Judd J D, Sarin S C, and Cundiff J S (2011) An optimal storage and transportation system for a cellulosic ethanol bio-energy plant. ASABE Paper No. 109413., St. Joseph, MI: ASABE.

[59] Cundiff J S, Grisso R D, and Ravula P P (2004) Management system for biomass delivery at a conversion plant. ASAE/CSAE Paper No. 046169, St. Joseph, MI: ASABE

[60] Eranki, P.L., Bryan D. Bals, and Bruce E. Dale. 2011. Advanced regional biomass processing depots: a key to the logistical challenges of the cellulosic biofuel industry. Biofuels, Bioprod. Bioref. DOI:10.1002/bbb. Society of Chemical Industry and John Wiley \& Sons, Ltd.

[61] Yoshioka T, Aruga K, Nitami T, Sakai H, and Kobayashi H (2006) A case study on the costs and the fuel consumption of harvesting, transporting, and chipping chains for logging residues in Japan. Biomass Bioenergy 30:342-348

[62] Ranta T (2005) Logging residues from regeneration fellings for biofuel production-a GIS-based availability analysis in Finland. Biomass Bioenergy 28:171-182.

[63] Ranta T, and Rinne S (2006) The profitability of transporting uncomminuted raw materials in Finland. Biomass Bioenergy 30:231-237.

[64] Ayoub N, Martins R, Wang K, Seki H, and Naka Y (2007) Two levels decision system for efficient planning and implementation of bioenergy production. Energy Conv. Man. 48:709-723.

[65] Cundiff J S, Shapouri H, and Grisso R D (2007) Economic analysis of two receiving facility designs for a bioenergy plant. ASABE Paper No. 076051, St. Joseph, MI: ASABE

[66] Brownell D, and Liu J (2012) Managing biomass feedstocks: selection of satellite storage locations for different harvesting systems. Agric. Engng Int'l CIGR Journal, 14(1): Manuscript No. 1886. 13 pp. 
[67] Cromer K (2011) Personal communication. FDC Enterprises-led Consortium. Antares Group Inc., 57 S. Main St., Suite 506, Harrisonburg, VA 22801. Cooper, Sam, courtesy of Sugar Journal, P.O. Box 19084, New Orleans, LA 70179).

[68] Kelderman Mfg. to implement multi-bale handling unit. 